\title{
Efecto de las adiciones puzolánicas en la retracción de pastas y morteros de cemento en sus primeras edades
}

\author{
The effect of pozzolan additions on the shrinkage \\ of cement pastes and mortars during \\ their first hours of age
}

M. MAURICIO OSSA y D. JORGE DAVID
Investigadores, IDIEM, Universidad de Chile

Fecha de recepción: 3-II-92

SANTIAGO (CHILE)

\section{RESUMEN}

La tradicional aceptación en Chile de los cementos con adición y su diversidad de usos, requiere de una amplia investigación sobre su comportamiento para que los resultados avalen su utilización en proyectos determinados. En este trabajo se estudiaron los cambios volumétricos que se producen en las primeras horas de edad en pastas $y$ morteros de cemento con adición puzolánica, comparándolos entre sí y relacionándolos con otras propiedades de dichos cementos. Para ello se utilizaron cementos fabricados a escala de laboratorio con materias primas provenientes de fábricas nacionales. Se emplearon dos tipos de clínker diferentes, un tipo de yeso y un tipo de puzolana natural, adicionada en proporciones entre $0 y$ $30 \%$. Se realizaron ensayos para determinar la retracción en pastas y morteros de cemento desde los primeros instantes de su amasado, utilizando para ello moldes dotados con un dispositivo especial diseñado e implementado en el Laboratorio de la Sección Aglomerantes del IDIEM.

Los resultados ratifican que, independientemente de las diferentes características de los cementos, la deformación en pastas y morteros presenta, en general, períodos de primera retracción, hinchamiento y segunda retracción.

La primera retracción se ve afectada por las condiciones ambientales de humedad, temperatura $y$ viento (evaporación), pero también influye en forma preponderante la superficie específica de los cementos que permite mayor velocidad en las reacciones químicas que ocurren en ese período. También incide aquí una menor o mayor compactación.

Por otro lado, se corroboró que a igualdad de finura, los cementos con mayor contenido de $C_{3} A$ presentan una mayor retracción total que los de bajo contenido.

Se pudo constatar, finalmente, que el aumento del contenido de puzolana no afecta directamente en el fenómeno de retracción, pero su presencia puede eventualmente modificar la razón yeso/clínker produciendo variaciones, especialmente en los estados de hinchamiento y segunda retracción.

\author{
$S U M M A R Y$
}

The traditional favour enjoyed by cement including additions and by their diverse uses in Chile calls for an extense investigation of their behaviour in order that the results may justify their utilization in specific projects. This works studies volume changes occurring in cement pastes and mortars containing pozzolan additions during their first hours of age. This investigation used cements made in the laboratory from raw materials supplied by chilean manufacturers. Two types of clinkers were used, namely; a gypsum type and a natural pozzolan type, added in proportions ranging from 0 to $30 \%$. Tests were conducted to ascertain the shrinkage of cement pastes and mortars since the first moments following their mixing operation, employing therefor moulds fitted with a special device designed and implemented at the laboratory of the IDIEM Department of Agglomerants.

The results thus gathered corroborated the fact that, independently of cement characteristics, in general the deformation of pastes and mortars exhibits successive periods of first shrinkage, swelling, and second shrinkage.

The first shrinkage is affected by the ambient conditions of humidity, temperature, and wind (evaporation), but also in a preponderant way by cement specific surface, which allows higher velocity in the chemical reactions occurring during that period. Moreover the compactation degree is also affecting shrinkage, here.

On the other hand, it was confirmed that with cements of like fineness, those having higher $C_{3} A$ contents exhibit an overall shrinkage larger than that of cements having low contents.

At last it was possible to ascertain that an increase in pozzolan contents does not affect shrinkage directly, but that its presence may evantually modify the gypsum/clinker ratio and thus give rise to changes, specially in the two states of swelling and second shrinkage. 


\section{INTRODUCCIÓN}

Existen muchos datos sobre la retracción que tiene lugar en pastas, morteros y hormigones a partir de las veinticuatro horas de su amasado. Sin embargo, pocos datos existen de los cambios volumétricos que ocurren antes de este tiempo, y esto es debido principalmente a las dificultades que se presentan en las medidas de estas variaciones volumétricas. Por otra parte, casi la generalidad de los estudios realizados sobre retracción se refieren a las características y comportamiento de cementos portland y muy pocos tratan sobre cementos con adiciones.

El objetivo de este trabajo experimental fue estudiar los cambios volumétricos que se producen en las primeras horas de edad en pastas y morteros de cemento con adición puzolánica.

Los ensayos se llevaron a efecto sobre probetas de $7 \times 7 \times 28 \mathrm{~cm}$, conservadas en un ambiente isotérmico y no agresivo durante el proceso de medición. Se trabajó con cementos existentes en el mercado y con cementos fabricados experimentalmente, empleando como materias primas dos tipos de clínkeres, un tipo de yeso y un tipo de puzolana natural, adicionada esta última en proporciones entre 0 y $30 \%$.

\section{CONOCIMIENTO ACTUAL DEL FENÓMENO DE RETRACCIÓN}

En una obra, la pasta de cemento del hormigón, saturada en un comienzo, se seca y endurece al mismo tiempo. Su retracción puede ser el resultado tanto de la desecación como de la hidratación.

Para llegar a una mayor comprensión, al menos cualitativa del fenómeno de la retracción de la pasta de cemento, es necesario analizar los resultados experimentales obtenidos en condiciones tales que los efectos de desecación y de hidratación estén separados. Las deformaciones que subsisten aun cuando se toman todas las precauciones para evitar la evaporación, son llamadas endógenas. La primera deformación de este tipo se manifiesta inmediatamente después de la colocación del hormigón en los moldajes, es el asentamiento yertical acompañado de exudación. La exudación y el asentamiento son dos aspectos de un mismo fenómeno. En la práctica, el asentamiento del hormigón fresco en los moldajes puede provocar fisuras igual o aun más que las otras deformaciones.

Cuando se mide la deformación de una probeta siguiendo una dirección horizontal, se elimina el asentamiento (que por ser un efecto del peso, es solamente vertical). Se obtiene entonces la curva representada en la figura 1.

\section{INTRODUCTION}

Many data are already available on shrinkage that takes place in pastes, mortars and concretes after the first 24 hours that follow their mixing step. However, there are few data on volume changes occurring before that shrinkage time, and the reason thereof is chiefly the difficulties arising when measuring these volume changes. In addition, almost all prior studies on shrinkage relate to the characteristics and behaviour of portland cements, and therefore very few studies are dealing with cements that include additions.

The aim of this experimental work was studying volume changes during the first hours of age of cement pastes and mortars containing pozzolan additions.

The tests were carried out using $7 \times 7 \times 28 \mathrm{~cm}$ specimens stored in an isothermal and non-agressive ambient during the measuring process. Work was undertaken using cements available on the market as well as experimental cements made from raw materials comprising two types of clinkers, one type of gypsum, and one type of natural pozzolan, this last one being added in a proportion raging form 0 to $30 \%$.

\section{PRESENT KNOWLEDGE OF SHRINKAGE PHENOMENON}

In a given construction the initially saturated cement paste of concrete is subjected to drying and to hardening at the same time. Its shrinkage can be the result of both drying and hydration.

In order to acquire a greater knowledge -al least qualitative on the shrinkage phenomenon happening in cement paste, the experimental results obtained should be analyzed in such conditions that the effects of drying and of hydration appear separately. The deformations that remain even after adopting all the precautions aimed at preventing evaporation, are termed endogenous. The first deformation of this sort occurs immediately after placing the cement in the forms and it is the vertical settling accompanied by exudation. Exudation and settling are two aspects of the same phenomenon. In practice, fresh-concrete settling in the formwork can bring about fissures in like fashion as other deformations, or even in a more pronounced way.

When the deformation of some specimen is measured along an horizontal direction, settling is eliminated (because it is only vertical, as an effect of weight). Then the curve shown in Figure 1 is obtained. 


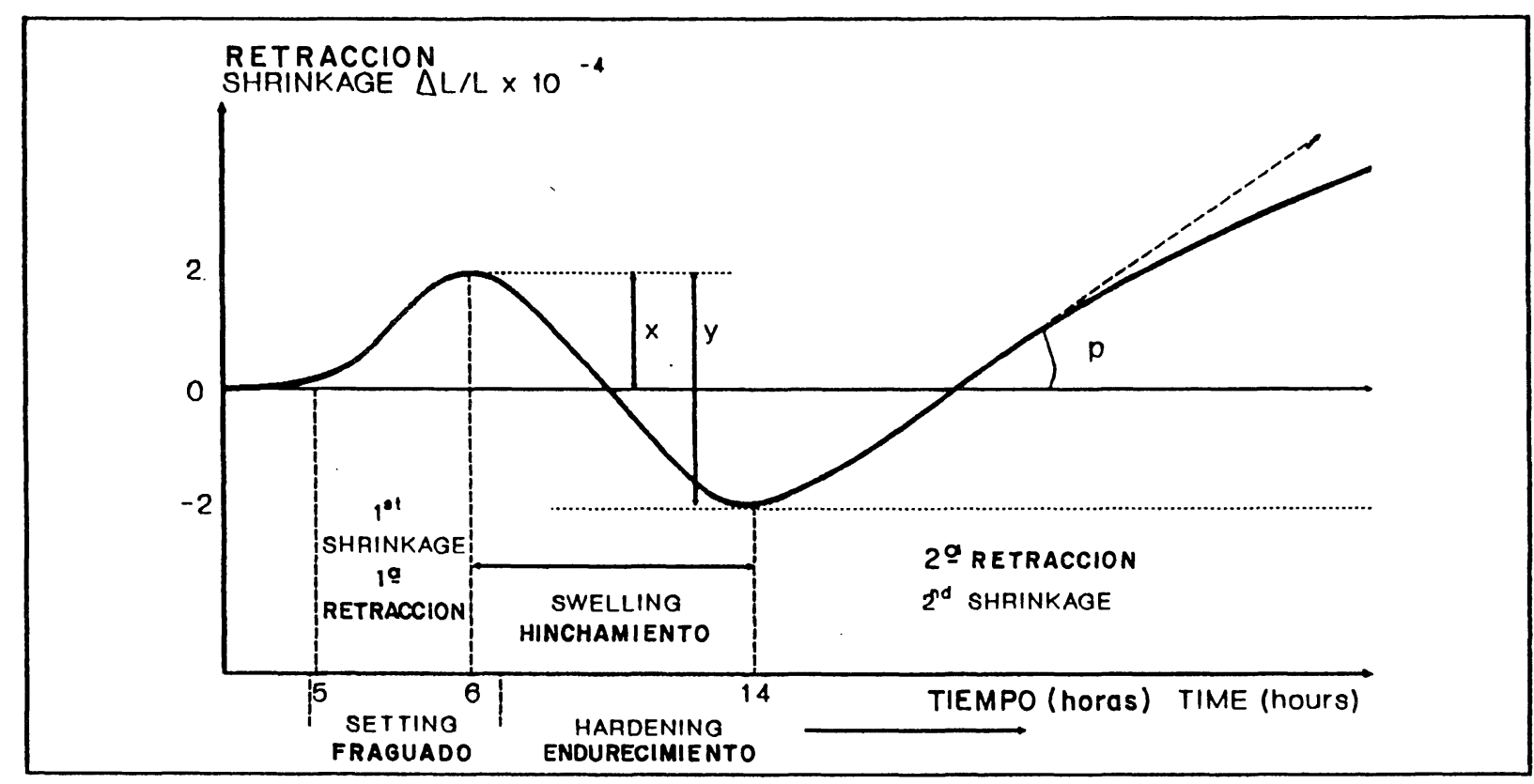

Fig. 1.-Deformación endógena de la pasta de cemento durante el envejecimiento.

Fig. 1.-Endogenous deformation of cement paste during aging.

En ella se aprecia la deformación de la pasta de cemento que envejece sin intercambio de agua con el exterior, distinguiéndose los tres estados de deformación: primera retracción, hinchamiento y segunda retracción. Las retracciones están consideradas positivamente y el origen de los tiempos corresponde al fin de mezclado. Los órdenes de magnitud dados en los ejes (retracciones y tiempos) son solamente indicativos y se designan por:

$x=$ el valor máximo de la primera retracción, $y=$ el valor máximo del hinchamiento,

$\mathrm{Z}=$ el valor máximo de la segunda retracción, $\mathrm{p}=$ la velocidad máxima de la segunda retracción.

\section{a) La primera retracción}

La primera retracción comienza casi al mismo tiempo en que ocurre el fraguado (al menos a $20^{\circ} \mathrm{C}$ ), típicamente, 1 a 3 horas después del término del mezclado, durando de 2 a 3 horas. Estos tiempos dados aquí, a título indicativo, son bastante representativos de los cementos corrientes, pero pueden variar por la incorporación de adiciones y aditivos (aceleradores o retardadores de fraguado) (1). El valor máximo de la primera retracción depende de la composición del cemento. Para ciertos cementos con bajo contenido de aluminato tricálcico $\left(\mathrm{C}_{3} \mathrm{~A}\right)$ casi no se observa una primera retracción sino más bien, desde el inicio, un hinchamiento. La primera retracción puede llegar a $6 \times 10^{-4}$ en el caso extremo de un cemento que contiene $15 \%$ de $\mathrm{C}_{3} \mathrm{~A}$ y rico en álcalis $\left(\mathrm{Na}_{2} \mathrm{y}\right.$
Figure 1 shows the deformation of cement past ageing without water exchange with the outside, and the three states of deformation are distinguishable therein, namely: first shrinkage, swelling, and second shrinkage. Shrinkages are plotted positively, and time origin corresponds to mixing completion. The orders of magnitude set out on the axes (shrinkages and times) are only indicative and they have the following meanings:
$x=$ maximum value of first shrinkage,
$y=$ maximum value of swelling,
$z=$ maximum value of second shrinkage,
$p=$ maximum velocity of second shrinkage.

\section{a) The first shrinkage}

The first shrinkage starts almost at the same time as setting (at least at $20^{\circ} \mathrm{C}$ ), typically 1 to 3 hours after mixing-end and lasts during 2 to 3 hours. These times given as indicative here, are fairly representative of common cements but they can be changed through the inclusion of additions and additives (setting agents or setting retarders) (1). The maximum value of the first shrinkage depends on cement composition. For certain cements exhibiting a low contents of tricalcium aluminate $\left(\mathrm{C}_{4} \mathrm{~A}\right)$ a first shrinkage is almost absent and it is replaced instead by swelling since the beginning. First shrinkage can reach $6 \times 10^{-4}$ in the extreme instance of a cement containing $15 \%$ $\mathrm{C}_{3} \mathrm{~A}$ and rich in alkalis $\left(\mathrm{Na}_{2}\right.$ and $\left.\mathrm{K}_{2} \mathrm{O}\right)$ with a ratio $w / c=0.3$. It seems that the maximum value of the first shrinkage increases with decreasing values of 


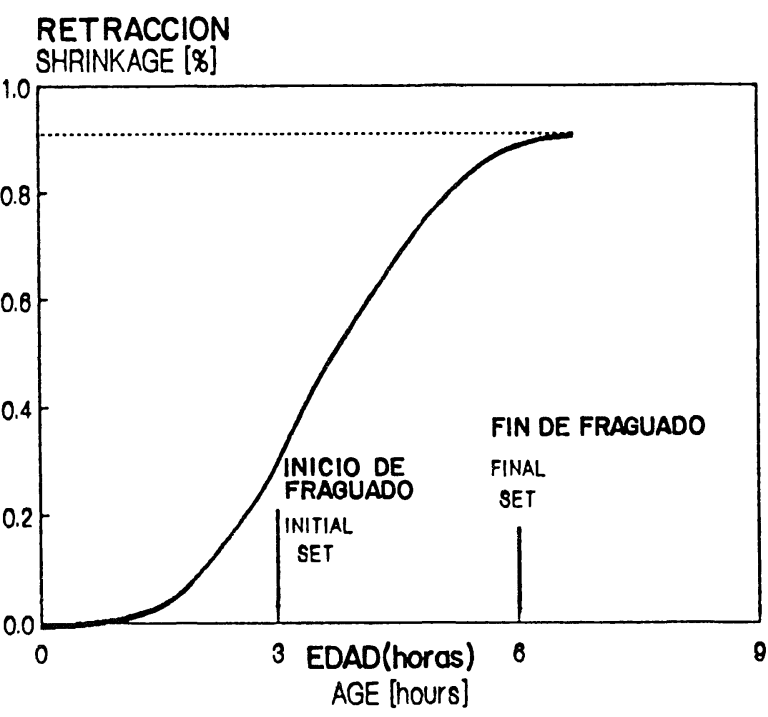

Fig. 2.-Primera retracción por desecación de un mortero de cemento de razón a/c igual a 0,5 , en condiciones ambientales de: $\mathrm{T}=20^{\circ} \mathrm{C}$, H.R. $=45 \%$.

Fig. 2. - First shrinkage throug the drying of a cement mortar exhibiting the ratio $w / c=0.5$, in ambient conditions of: $T=$ $20^{\circ} \mathrm{C}$, relative humidity $=45 \%$.

$\mathrm{K}_{2} \mathrm{O}$ ) con una razón a/c igual a 0,3. Parece que el valor máximo de la primera retracción aumenta cuando la razón a/c disminuye (2); es, sin embargo, bastante débil si se compara con la retracción denominada "plástica" que se produce a la misma edad si la probeta está expuesta al secado (Fig. 2).

Duracción: en la práctica la primera retracción comienza después que la superficie expuesta de la probeta está seca, es decir, exenta de agua superficial. Ello se produce después que el flujo de agua evaporada llega a ser superior al flujo de agua exudada. Esto último es estacionario durante el prefraguado y decrece bruscamente en el momento del comienzo del fraguado. Es entonces cuando comienza la primera retracción en las condiciones climáticas usuales de las regiones templadas. En cambio, para viento calido y seco el flujo de agua evaporada puede ser superior al flujo estacionario de agua exudada, y la primera retracción se manifiesta entonces muy pronto, algunas decenas de minutos después de la colocación (3).

El frío o los aditivos retardadores de fraguado pueden aumentar la duracción de la primera retracción, luego también su valor final.

Velocidad: La velocidad de la primera retracción es semsiblemente proporcional a la velocidad de evaporación del agua interna (4). Esta última depende de la presión de vapor (luego de la temperatura ambiente) y de la velocidad del viento. El efecto del viento es a menudo preponderante. En aire calmado, a $45 \%$ de
PRIMERA RETRACCION

FIRST SHRINKAGE [X]

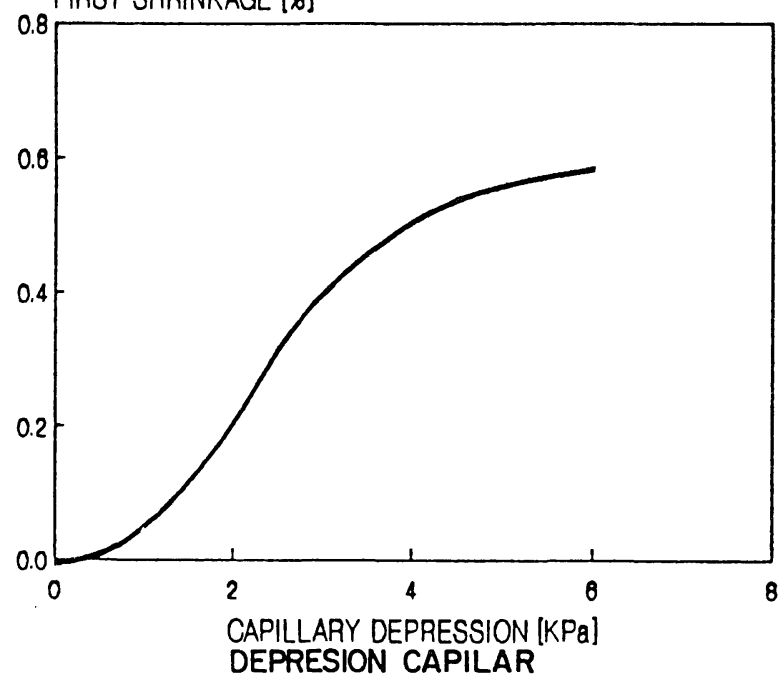

Fig. 3.-Primera retracción y depresión capilar.

Fig. 3.-First shrinkage and capillary depression.

$w / c$ ratio (2); however, this shrinkage is fairly weak in comparison with the shrinkage termed "plastic" and occurrring at the same age if the specimen is subject to drying (Figure 2).

Duration: In practice, the first shrinkage starts afther the drying of the exposed surface of the specimen, i.e. after the absence of superficial water. This happens afther the flow of evaporated water exceeds the flow of exuded water. This latter process remains stationary during presetting and decreases in an abrupt way at the time of setting initiation. Then the first shrinkage is started in the usual climatic conditions prevailing in temperate regions. By contrast, in the case of warm and dry wind the flow of evaporated water can exceed the stationary flow of exudated water and then the first shrinkage happened very early, namely a few tens of minutes after placing the material (3).

Cold and setting-retarder additives can increase the duration of the first shrinkage and hence also its final value.

Velocity: First shrinkage velocity is approximately proportional to the velocity of internal-water evaporation (4). This last one depends on steam pressure (hence on ambient temperature), and on wind velocity. Frequently, wind effect is preponderant. In still air with $45 \%$ relative humidity the end-value of the first shrinkage of 
humedad relativa, el valor final de la primera retracción de un mortero es del orden de $0,8 \% 10^{-3}$, y con un viento de $8 \mathrm{~m} / \mathrm{s}, 30 \mathrm{~km} / \mathrm{h}$, es 10 veces mayor (Fig. 2). Hay que notar que la evaporación es endotérmica y enfría por consiguiente la vecindad de la superficie expuesta, a veces hasta en $8^{\circ} \mathrm{C}$. La desecación varía con la profundidad. La retracción a $10 \mathrm{~cm}$ de profundidad es igual al $60 \%$ del valor medido a $3,5 \mathrm{~cm}$ de la superficie (6).

El mecanismo de retracción por depresión capilar se verifica mejor para la primera retracción que para la retracción de la pasta endurecida porque antes del fraguado gran parte de los capilares tiene una dimensión superior al micrón. Se puede mostrar que al comienzo de la desecación, la primera retracción aumenta con la depresión capilar (5) (Fig. 3).

En la primera retracción contribuye también el proceso de carbonatación. Este efecto resulta de la reacción del dióxido de carbono del aire con el hidróxido de calcio producido durante la hidratación del cemento para formar carbonato de calcio: el hidróxido de calcio es disuelto, el carbonato precipita y se libera agua.

El resultado de este análisis es que la retracción por desecación (o por autodesecación, que viene a ser lo mismo) es ciertamente la más sistemática, luego la más importante, siendo la retracción por carbonatación una consecuencia de la retracción por desecación.

\section{b) El hinchamiento}

El término de la primera retracción coincide más o menos con el fin del fraguado. Sobreviene entonces un hinchamiento cuya duración y amplitud varían mucho según los cementos, aun dentro de una misma clase de resistencia. Para ciertos cementos ricos en $\mathrm{C}_{3} \mathrm{~A}$ y subdosificados en yeso puede no haber ningún hinchamiento, sino que apenas una disminución momentánea de la retracción. A veces el período de hinchamiento existe, pero es muy corto (menos de 3 horas). Sin embargo, para numerosos cementos, a $20^{\circ} \mathrm{C}$, este período dura entre 10 y 20 horas y alcanza un máximo del orden de $4 \times 10^{-4}$ (para a/c igual a $0,27)$. El hinchamiento depende de la cantidad de cal libre que permanece no hidratada al término del fraguado y aumenta fuertemente con la temperatura. La influencia de la dosificación en agua (razón a/c) no está determinada (1). Según Baron (6) y del Campo (7), el hinchamiento de los cementos portland depende del contenido en sulfato y aluminato. Aumenta generalmente con el porcentaje de $\mathrm{SO}_{3}$ o el porcentaje de $\mathrm{Al}_{2} \mathrm{O}_{3}$.

Cuando se conserva la pasta de cemento bajo el agua, de manera que el agua pueda penetrar en sus capilares, se impide la autodesecación. Se observa entonces un hinchamiento que perdura some mortar is on the order of $0.8 \% 10^{-3}$, while a wind of $8 \mathrm{~m} / \mathrm{s}, 30 \mathrm{~km} / \mathrm{h}$, produces a value 10 times higher (Figure 2). It should be noticed that evaporation is endothermic and hence it cools - sometimes by up to $8^{\circ} \mathrm{C}$ - the space surrounding the exposed surface. Drying varies with depth. Shrinkage at $10 \mathrm{~cm}$ depth amounts to $60 \%$ of the value measured at $3.5 \mathrm{~cm}$ under the surface (6).

The mechanism of shrinkage through capillary depression occurs for the first shrinkage in a better way than for the shrinkage of the hardened paste, because prior to setting a major portion of the capillaries has a dimension exceeding one micron. It can be shown that the first shrinkage increases with capillary depression, at the beginning of the drying process (5). (Figure 3).

The carbonation process also contributes to the first shrinkage. This effect derives from the reaction between atmospheric carbon dioxide and calcium hydroxide produced during cement carbonation to thus yield calcium carbonate; the calcium hydroxide is dissolved, the carbonate is precipitated, and the water is released.

The above analysis shows that shrinkage through drying (or through self-drying, which is the same thing) is certainly the most systematic and hence the most important, shrinkage through carbonation being a consequence of shrinkage through drying.

\section{b) The swelling}

The end of the first shrinkage is more or less coincident with setting completion. Then a swelling occurs, whose duration and amplitude are very variable in accordance with the cements, even within the same class of strength. Some $C_{3} A$-rich cements underproportioned in gypsum can be exempt from swelling and exhibit a scarse momentaneous reduction in shrinkage.

Sometimes the swelling period exists but is very short (lasting less than 3 hours). However, for numerous cements this period lasts between 10 and 20 hours, at $20^{\circ} \mathrm{C}$, and reaches than a maximum on the order of $4 \times 10^{4}$ (for $w / c=0.27)$. Swelling depends on the free lime that remains non-hydrated on setting completion, and it increases strongly with temperature. The influence of water contents ( $w / c$ ratio) is not determined (1). According to Baron (6) and del Campo (7), swelling of portland cements depends on sulphate and aluminate contents. In general this swelling increases with an increasing percentage of either $\mathrm{SO}_{3}$ or $\mathrm{Al}_{2} \mathrm{O}_{3}$.

Self-drying is prevented when the cement paste is kept underwater so that water may enter its capillaries. Then it is possible to observe a certain swelling that lasts even after 1000 days of 


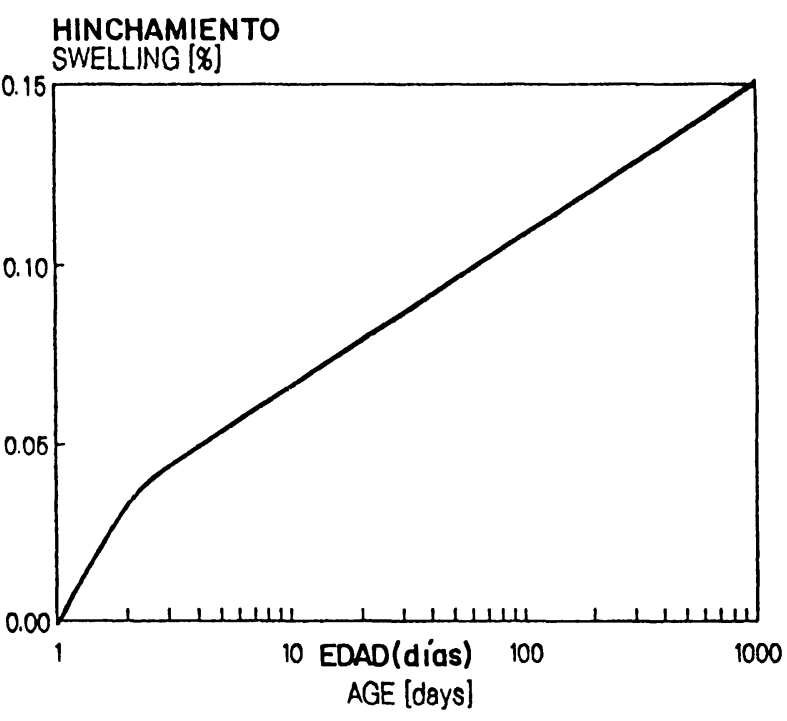

aun después de 1.000 días de hidratación y puede llegar a 0,2\% (Fig. 4). En el curso de los primeros días, una parte de ese hinchamiento de origen químico se debe netamente a la formación de ettringita. El hinchamiento a largo plazo, por el contrario, está ligado a la estructuración de la pasta por hidratación y, en particular, al aumento considerable de las superficies específicas.

\section{c) La segunda retracción}

Se manifiesta después del fin de fraguado. Para deformaciones restringidas iguales, las contracciones en juego son, por consiguiente, mucho más fuertes para la segunda retracción que para la primera. El valor de la segunda retracción de una pasta de cemento cuya razón a/c está comprendida entre 0,25 y 0,30 puede llegar a $1,5 \times 10^{-3}$ en un lapso de 7 días, en condiciones de temperatura ambiental constante e igual a $20^{\circ} \mathrm{C}$ y en ausencia de pérdida de agua por evaporación. La velocidad máxima de la segunda retracción (Fig. 1) varía considerablemente según los cementos, aun dentro de una misma clase de resistencia. Para una razón $a / c$ igual a 0,27 , los valores se extienden de 0,2 a $7 \times 10^{-5}$ por hora. Parece, grosso modo, que cuanto más tiempo dura el hinchamiento, la velocidad máxima de la segunda retracción es menor. Esta velocidad aumenta cuando la razón a/c disminuye (1).

Según Baron (9), la velocidad máxima de la segunda retracción, es tanto mayor cuanto mayores sean los contenidos de aluminato, de magnesio y de álcalis, más alejado se encuentre el yeso de su valor óptimo y más fino sea el cemento.

Para explicar las deformaciones que ocurren en las pastas de cemento durante el envejecimiento J. Baron (1) propone las 3 causas que se señalan en la tabla I.
Fig. 4. - Hinchamiento de una probeta de pasta de cemento conservada bajo el agua a $20^{\circ} \mathrm{C}(\mathrm{a} / \mathrm{c}$ igual a 0,25$)(8)$.

Figure 4.- Swelling of a cement-paste especimen kept underwater at $20^{\circ} \mathrm{C}(w / \mathrm{c}=0.25)(8)$.

hydration and that can reach $0.2 \%$ (Figure 4). During the first days a portion of this swelling of chemical origin is clearly due to ettringite formation. On the contrary, long-term swelling is linked to the structuration of the paste through hydration and, particularly, to the considerable increase in the specific surfaces.

\section{c) The second shrinkage}

The second shrinkage appears on setting completion. Hence, in the case of restricted deformations the contractions are much stronger for the second shrinkage than for the first one. The second shrinkage of some cement paste whose $w / c$ ratio falls between 0.20 and 0.30 can reach the value of $1.5 \times 10^{-3}$ within a time of 7 days in constant ambient-temperature conditions of $20^{\circ} \mathrm{C}$ and in the absence of water-loss through evaporation. The maximum velocity of the second shrinkage (Figure 1) varies in a considerable fashion according to the cements, even within the same class of strength. For a $w / c$ ratio amounting to 0.27 the values range from 0.2 to $7 \times 10^{-5}$ per hour. It seems, grosso modo, that the longer the swelling period the lower the maximum velocity of the second shrinkage. This velocity increases with a decreasing $w / c$ ratio (1).

According to Baron (9), the maximum velocity of the second shrinkage increases with increasing values of aluminate, magnesium and alkali contents, with gypsum values increasingly distant from its optimum value, and with an increasing fineness of cement.

J. Baron (1) explains the deformations occurring in cement pastes during ageing by setting forth the 3 causes given in Table $I$. 
TABLA I

Mecanismos de la deformación endógena de las pastas de cemento

\begin{tabular}{|l|c|c|c|}
\hline \multirow{2}{*}{\multicolumn{2}{|c|}{ Mecanismos }} & \multicolumn{2}{c|}{ Fenómenos } \\
\cline { 2 - 4 } & $\begin{array}{c}\text { Período de } \\
\text { fraguado }\end{array}$ & \multicolumn{2}{c|}{ Periodo de endurecimiento } \\
\cline { 2 - 4 } & 1.2 retracción & Hinchamiento & 2.2 retracción \\
\hline Autodesecación & $X X$ & $X$ & $X X$ \\
\hline Deformación térmica & & $X$ & $X$ \\
\hline Formación de ettringita & $X$ & $X X$ & $X$ \\
\hline
\end{tabular}

XX Mecanismo preponderante.

$X$ Mecanismo secundario.

$\varnothing$ La importancia depende de la forma y de la sección de la pieza.

TABLE I

Mechanisms of the endogenous deformation of cement pastes

\begin{tabular}{|c|c|c|c|}
\hline \multirow{3}{*}{ Mechanisms } & \multicolumn{3}{|c|}{ Phenomena } \\
\hline & \multirow{2}{*}{$\begin{array}{c}\text { Setting period } \\
\begin{array}{c}\text { First } \\
\text { shrinkage }\end{array}\end{array}$} & \multicolumn{2}{|c|}{ Hardening period } \\
\hline & & Swelling & $\begin{array}{l}\text { Second } \\
\text { shrinkage }\end{array}$ \\
\hline Self-drying & $x x$ & $x$ & $X X$ \\
\hline Thermal deformation & & $x$ & $x \times \varnothing$ \\
\hline Ettringite formation & $x$ & $x X$ & $x$ \\
\hline
\end{tabular}

XX Preponderant mechanism.

$X$ Secondary mechanism.

$\varnothing$ The importance depends on the shape and cross-section of the part.

\section{ESTUDIOS PRECEDENTES}

Las investigaciones realizadas, tanto en pastas puras, morteros $u$ hormigones, han pretendido establecer métodos de medida de la retracción en probetas de distintas formas y tamaños, afectadas por diversos factores.

Ossa, M., Cofré, F. y Marcantonini, C. (10) realizaron experiencias con pasta pura de cemento. Las pastas se prepararon con consistencia normal y, debido a la compresión aplicada con una máquina para moldear las probetas, se expulsaba agua quedando una razón a/c aproximada de 0,20 . Las probetas utilizadas eran prismáticas de $10 \times 10 \times 40 \mathrm{~mm}$ y se sometieron a mediciones por un tiempo que se prolongó desde una hora hasta 28 días. Los resultados indicaron que los valores máximos de

\section{PRIOR STUDIES}

The prior investigations covering neat pastes, mortars or concretes have endeavoured to establish methods for measuring shrinkage happening in specimens of diverse shapes and sizes, affected by sundry factors.

Ossa M., Cofré F., and Marchantonini C. (10) conducted experiences using neat paste of cement. The pastes were prepared with normal consistency and as a result of the compression through a specimen moulding-machine, water was expelled so as to leave a w/c ratio of about 0.20 . The prismatic specimens employed measured $10 \times 10 \times 40 \mathrm{~mm}$ and they were subjected to measurement for a time period ranging from one hour to 28 days. The results indicated that the maximum values of shrinkage varied within the 
retracción variaron dentro del rango de 1,75 a $4,10 \mathrm{~mm} / \mathrm{m}$, y las velocidades máximas de segunda retracción fluctuaron entre 0,131 y $0,205 \mathrm{~mm} / \mathrm{m} / \mathrm{h}$.

Ravina, D. y Shalon, R. (11) realizaron experiencias en prismas de mortero de $7 \times 7 \times 28 \mathrm{~cm}$ a una profundidad de $0,7 \mathrm{~cm}$ bajo la superficie de la probeta. Los resultados indicaron que la retracción medida varió dentro del rango de 3 a $10 \mathrm{~mm} / \mathrm{m}$ y que la retracción de los morteros semiplásticos fue notablemente más pequeña que la alcanzada por los de consistencia plástica y fluida.

Según Dutron, R. y Mommens, A. (12) las condiciones climáticas tienen una influencia preponderante sobre la primera retracción; temperatura, higrometría y viento, sobre todo: a $20^{\circ} \mathrm{C}$ y $45 \%$ de H.R., el valor máximo de la primera retracción del mortero es, por ejemplo de $0,8 \times 10^{-3}$, con un viento en calma y de $8 \times 10^{-3}$ con un viento de $8 \mathrm{~m} / \mathrm{s}(29 \mathrm{~km} / \mathrm{h})$.

Baron, J. (6) señala que para una pasta de cemento expuesta a un ambiente de $20^{\circ} \mathrm{C}$ y $50 \%$ de H.R., la tensión máxima es de alrededor de $0,13 \mathrm{~kg} / \mathrm{cm}^{2}$. La resistencia a la tracción de un mortero de 8 horas de edad es de, aproximadamente, $1,2 \mathrm{~kg} / \mathrm{cm}^{2}$, y a esta edad la primera retracción es casi la máxima. Con un viento de $30 \mathrm{~km} / \mathrm{h}$ la retracción sería indudablemente multiplicada por diez y podría provocar la ruptura. (Un producto de curado eficaz, convenientemente aplicado, puede bastar para evitar ese tipo de fisura).

Ossa, M. y Rosales, O. (13) encontraron resistencias de $8,6 \mathrm{~kg} / \mathrm{cm}^{2}$ a compresión y $1,2 \mathrm{~kg} / \mathrm{cm}^{2}$ a tracción por hendimiento a 8 horas de edad en probetas confeccionadas con cementos portland puzolánicos (Fig. 5). También midieron la retracción en probetas de mortero estableciendo determinadas condiciones climáticas, conjugando las variantes temperatura, humedad relativa y velocidad del aire en el interior de un túnel de viento, utilizando diales de precisión. Las probetas eran prismáticas y median $4 \times 4 \times 31 \mathrm{~cm}$. Los resultados mostraron que:

- La influencia de las distintas configuraciones de factores ambientales y de composición de la mezcla, sobre la retracción plástica, se reflejó en su velocidad que varió desde 1,5 a $5,0 \mathrm{~mm} / \mathrm{m} / \mathrm{h}$ y en el valor final de retracción que osciló entre 3,6 y $4,9 \mathrm{~mm} / \mathrm{m}$.

- Cuando la velocidad del viento se disminuyó de 25 a $5 \mathrm{~km} / \mathrm{h}$, la retracción plástica se redujo aproximadamente en un $13 \%$.

- Cuando la temperatura ambiente bajó de 40 a $25^{\circ} \mathrm{C}$ se produjo una disminución de alrededor de un $7 \%$ en la retracción plástica. range of 1.75 to $4.10 \mathrm{~mm} / \mathrm{m}$ while the maximum velocities of the second shrinkage fluctuated between 0.131 and $0.205 \mathrm{~mm} / \mathrm{m} / \mathrm{h}$.

Ravina D. and Shalon $R$. (11) used mortar prisms of $7 \times 7 \times 28 \mathrm{~cm}$ in order to carry out experiences at a depth of $0.7 \mathrm{~cm}$ under specimen surface. The results showed that the measured shrinkage varied within the range of 3 to $10 \mathrm{~mm} / \mathrm{m}$ and that the shrinkage of semiplastic mortars was subtantially smaller than that exibited by the mortars of plastic and fluid consistency.

According to Dutron R. and Mommens A. (12) the cimatic conditions exert a preponderant influence on the first shrinkage; temperature, hygrometry and wind, above all: at $20^{\circ} \mathrm{C}$ and $45 \%$ relative humidity the maximum value of the first shrinkage of mortar amounts for instance to $0.8 \times 10^{-3}$ with a wind of $8 \mathrm{~m} / \mathrm{s}(29 \mathrm{~km} / \mathrm{h})$.

Baron J. (6) indicates that the maximum tension reaches about $0.13 \mathrm{~kg} / \mathrm{cm}^{2}$ for a cement paste exposed to an ambient of $20^{\circ} \mathrm{C}$ and $50 \%$ relative humidity. Tensile stress of a mortar at 8 hours of age is approximately equal to $1.2 \mathrm{~kg} / \mathrm{cm}^{2}$ and at that time the first shrinkage is almost the maximum one. With a wind of $30 \mathrm{~km} / \mathrm{h}$ the shrinkage would doubtless be multiplied by ten and might cause a rupture. (Some efficient curingproduct convenientiy applied can suffice to avoid this type of fissure).

Ossa M. and Rosales $O$. (13) found compressive strengths of $8.6 \mathrm{~kg} / \mathrm{cm}^{2}$ and tensile strengths of $1.2 \mathrm{~kg} / \mathrm{cm}^{2}$ through splitting at the age of 8 hours using specimens made of portland-pozzolan cements (Figure 5). They also measured shrinkage in specimens of mortar, establishing therefor determined climatic conditions by combining the variables of temperature, relative humidity and air velocity within a wind-tunnel, using precision dials. The specimens were prismatic and measured $4 \times 4 \times 31 \mathrm{~cm}$. The results showed the following particulars:

- The influence, on plastic shrinkage, of the diverse combinations of ambient factors and of mixture compositions, was reflected in shrinkage velocity, which varied from 1.5 to $5.0 \mathrm{~mm} / \mathrm{m} / \mathrm{h}$, and in the end value of shrinkage, which oscillated between 3.6 and $4.9 \mathrm{~mm} / \mathrm{m}$.

- Plastic shrinkage decreased by about $13 \%$ when wind velocity was decreased from 25 to $5 \mathrm{~km} / \mathrm{h}$.

- Ambient-temperature reduction from 40 to $25^{\circ} \mathrm{C}$ decreased plastic shrinkage by about $7 \%$. 
RESISTENCIA A TRACCION POR HENDIMIENTO

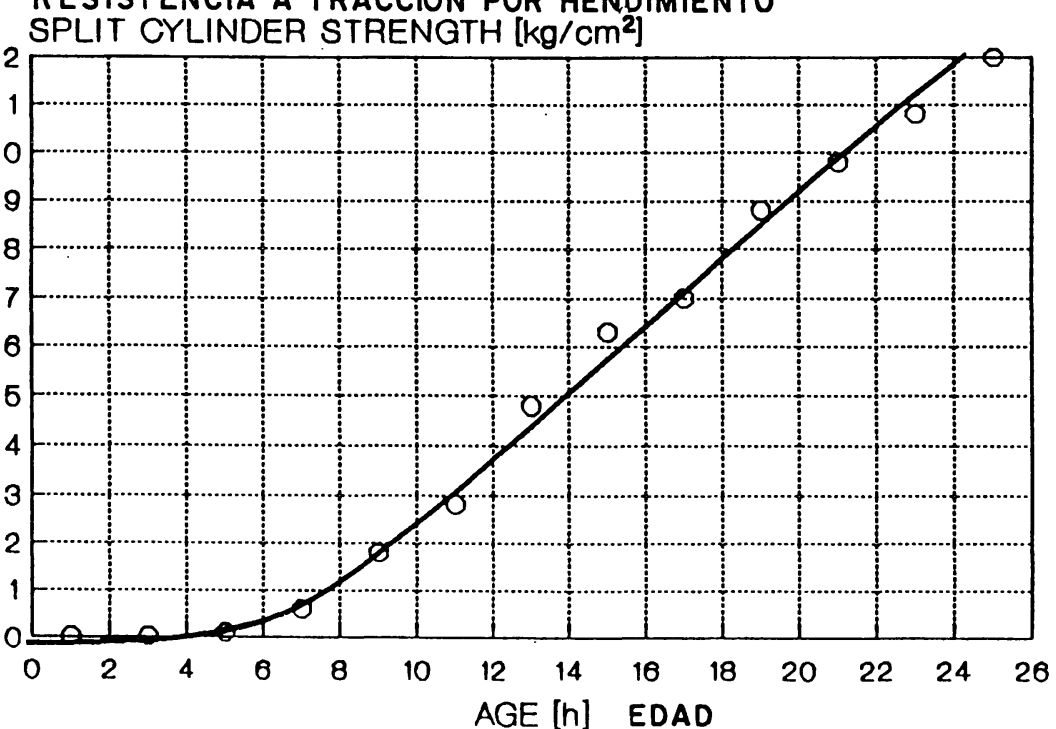

Fig. 5.-Resistencia a tracción por hendimiento de mortero normal.

Fig. 5.-Tensile stress throught splitting of normal mortar.

- Cuando disminuyeron conjuntamente la velocidad del viento y la temperatura ambiente, de 25 a $5 \mathrm{~km} / \mathrm{h}$ y de 40 a $25^{\circ} \mathrm{C}$ respectivamente, se redujo la retracción plástica en alrededor de un $25 \%$.

- En un ambiente húmedo, con temperatura de $25^{\circ} \mathrm{C}$, velocidad de viento de $5 \mathrm{~km} / \mathrm{h}$ y humedad relativa entre 50 y $75 \%$, la retracción plástica disminuyó en un $26 \%$ con respecto a un ambiente seco con temperatura de $40^{\circ} \mathrm{C}$, velocidad de viento de $25 \mathrm{~km} / \mathrm{h}$ y humedad entre 25 y $50 \%$.

Baron, J. (14) midió la segunda retracción de un cemento portland utilizando una probeta cilíndrica de $20 \mathrm{~mm}$ y de $160 \mathrm{~mm}$ de altura. Los resultados mostraron que una variación de un 1,2\% en la cantidad del agua de amasado se traduce en una disminución de $18 \%$ en la velocidad máxima de la segunda retracción y en un retraso de dos horas en la aparición de la segunda retracción.

\section{EXPERIMENTACIÓN A NIVEL DE LABORATORIO}

Los cementos con adición puzolánica son de aceptación cada vez más frecuente. En Chile seis de los cementos comerciales que se producen tienen este tipo de adición. Sin embargo, en obras de hormigón, en donde la retracción plástica es una variable importante, inquieta a veces el desconocimiento que se tiene sobre la influencia de las adiciones puzolánicas frente a este fenómeno.
- The simultaneous reduction of wind velocity from 25 to $5 \mathrm{~km} / \mathrm{h}$ and of ambient temperature from 40 to $25^{\circ} \mathrm{C}$, decreased plastic shrinkage by about $25 \%$.

- In a humid ambient with $25^{\circ} \mathrm{C}$ temperature, 5 $\mathrm{km} / \mathrm{h}$ wind velocity, and 50 to $75 \%$ relative humidity, the plastic shrinkage decreased by about $25 \%$ in comparison with a dry ambient with $40^{\circ} \mathrm{C}$ temperature, $25 \mathrm{~km} / \mathrm{h}$ wind velocity, and 25 to $50 \%$ relative humidity.

Baron, J. (14) measured the second shrinkage of a portland cement employing a cylindrical specimen $20 \mathrm{~mm}$ and $160 \mathrm{~mm}$ high. The results showed that a $1.2 \%$ variation in mixing-water contents causes a $18 \%$ reduction in the maximum velocity of the second shrinkage as well as a 2 hour delay in the appearance of this shrinkage.

\section{LABORATORY EXPERIMENTATION}

Cements including pozzolan additions are enjoying increasing favour. Six of the commercial cements now manufactured in Chile have this type of addition. However, as regards concrete constructions wherein plastic shrinkage is indeed an important factor, there sometimes arises a certain inquietude owing to a lack of sufficient knowledge about the influence of pozzolan addition on this shrinkage phenomenon. 


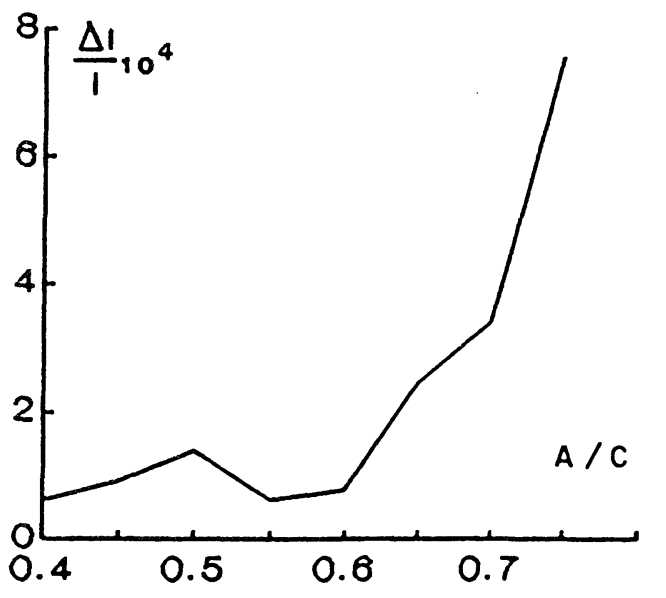

Evolución de la primera retracción de un mortero, a la edad de 8 horas en función de la razón ponderal agua/cemento. (Resultados obtenidos por J. T. Simeonov-Sofla, Bulgaria). Esta curva parece mostrar que varios fenómenos intervienen en la primera retracción. El valor a/c para el cual la primera retacción es mínima puede depender de condiciones experimentales, por razones especialmente de resudación.

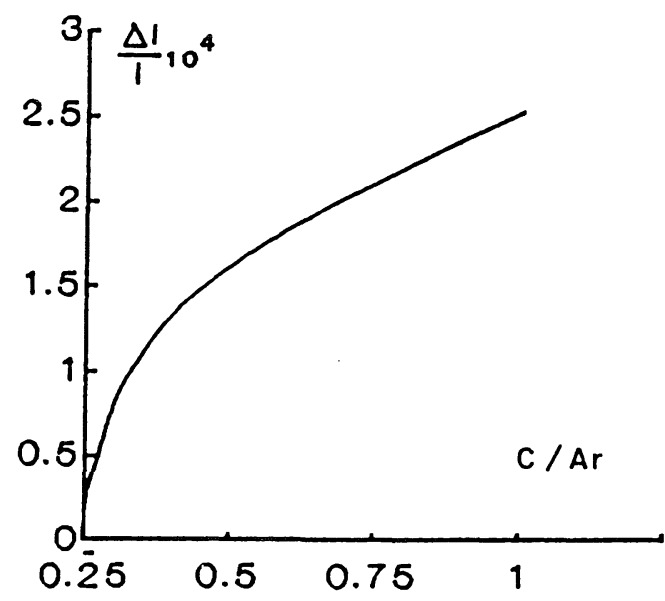

Evolución de la primera retracción de un mortero a la edad de 6 horas, on función do la reción pondera cementora Corresponde a la misma fuente del gráfico de la izquierda.

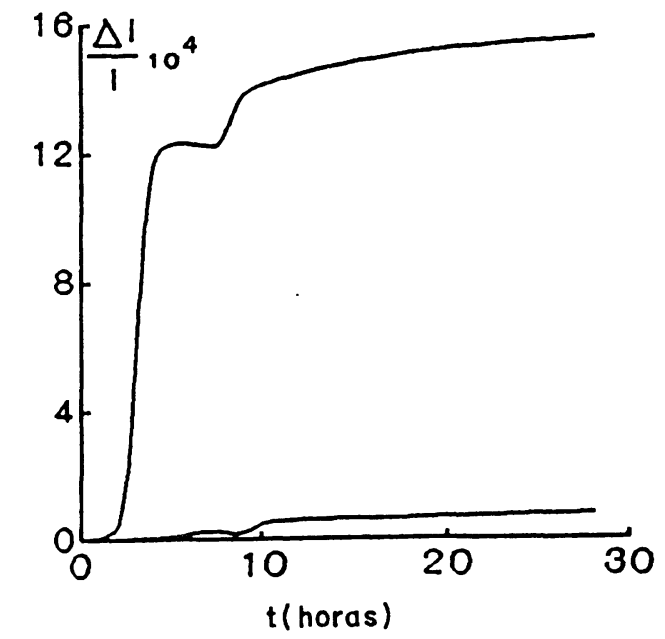

La curva superior muestra que, en pastas de cemento, la segunda retracción sobreviene bruscamente. Se puede constatar en la curva inferior que en mortero con el mismo cemento ocurre el mismo fenómeno. Estos resultados se obtuvieron en condiciones isotérmicas.

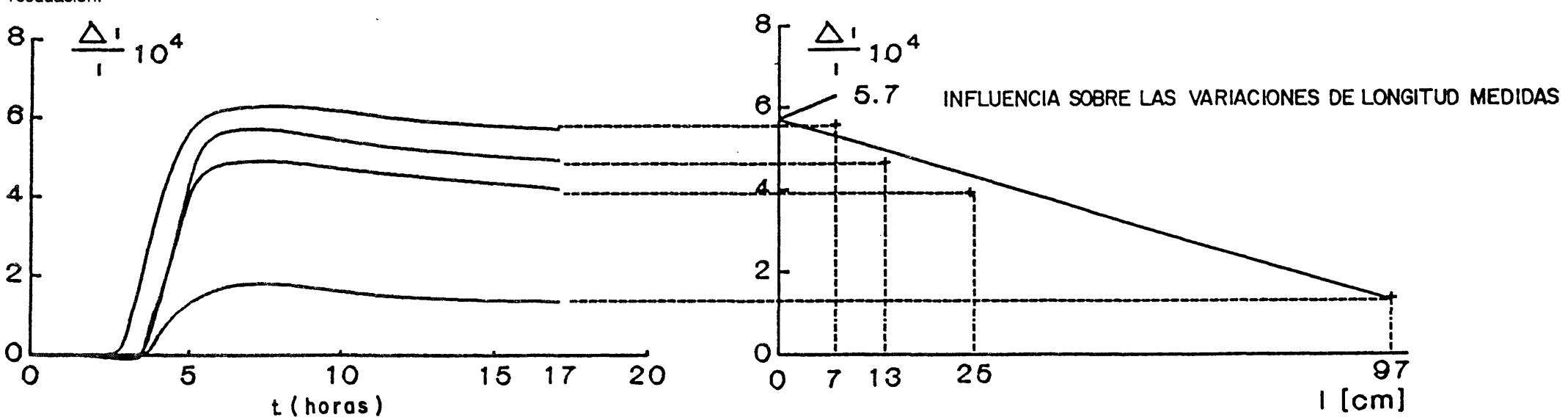

A la izquierda están representadas las variaciones relativas a la longitud de las probetas de 7, 13, 25 y $97 \mathrm{~cm}$ de largo. Mientras más larga es la probeta, es más débil la variación relativa de longitud. Por extrapolación (a la derecha) se puede deducir una estimación del valor de la retracción sin roce a la edad de 17 horas. Se constata (a la izquierda) que más allá del primer máximo las curvas son paralelas y que por consiguiente el roce no interviene.

Fig. 6. - Gráficos que muestran cómo afectan en el fenómeno de la retracción factores tales como: razón agua/cemento, relación cemento/arena, mediciones en pasta de cemento o en mortero $y$, finalmente, longitud de las probetas por roce de las paredes de los moldes (6). 


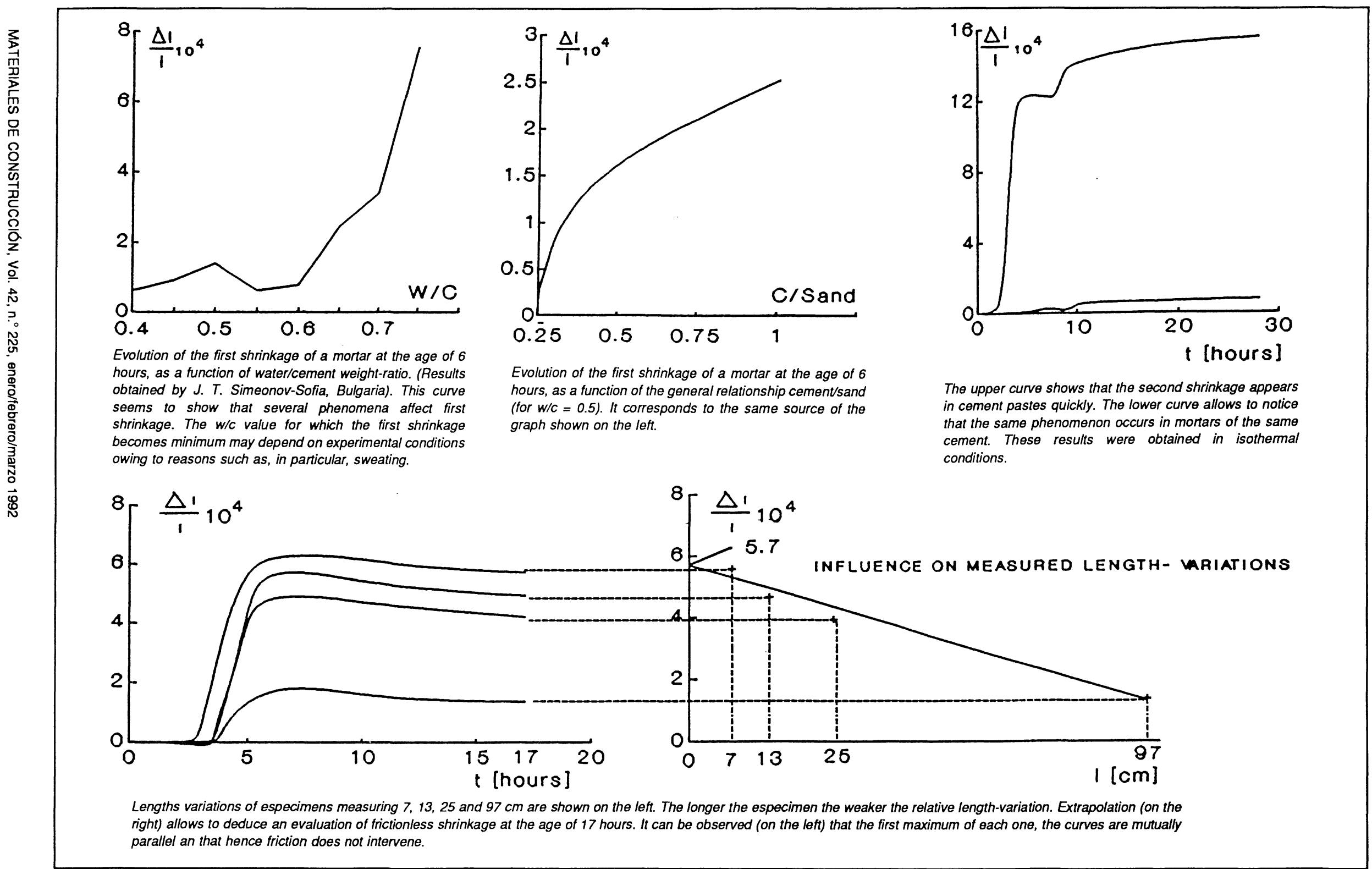

Fig. 6. - Graphs showing how shrinkage phenomenon is affected by factors such as: water/cement ratio, cement/sand relationship, measurements in cement paste or in mortar and, at last, specimen length according to the friction against mould sides (6). 
La mayoría de los trabajos experimentales, referentes a retracción, se han realizado con hormigones y éstos se han confeccionado, por lo general, con cementos portland. Ello hace resaltar la necesidad de realizar estudios de carácter experimental para calificar cualitativa y cuantitativamente un cemento desde el punto de vista de la retracción. Este trabajo pretende, entonces, estudiar el comportamiento de la retracción de cementos fabricados con materias primas nacionales. Para ello se utilizaron cementos obtenidos en forma industrial y experimental.

Los cementos obtenidos experimentalmente se diferencian de aquellos obtenidos a nivel industrial, por el tipo de molino empleado en la molienda, por las temperaturas alcanzadas por el cemento en el molino y por las pequeñas cantidades producidas. La preparación de materias primas y la molienda de los cementos experimentales se realizaron en la planta piloto de la estación experimental del IDIEM, ubicada en Los Cerrillos.

\section{Materias primas}

Clínker: El clínker para la fabricación de los cementos experimentales provino de dos fábricas nacionales, que gentilmente colaboraron con este estudio.

La composición química de los clínkeres se muestran en tabla II.

La composición potencial de las fases minerales correspondientes se muestra en tabla III.

Adición: La puzolana utilizada en este estudio provino de los yacimientos situados en la localidad de Pudahuel.

Las tablas IV y V muestran sus propiedades químicas y sus propiedades físicas respectivamente.

Yeso: La composición química del yeso empleado en la fabricación de los cementos experimentales se muestra en tabla VI.

\section{Preparación de las materias primas}

La molienda de los cementos experimentales se efectuó utilizando primeramente una chancadora de mandíbulas, con el propósito de reducir el tamaño tanto de los trozos de yeso natural como de las partículas de clínker comprendidas entre 3 y $20 \mathrm{~mm}$ de diámetro. Luego, se utilizó un molino cónico de bolas con sistema completo de clasificación por aire, marca Hardinge, que al recibir partículas de menor tamaño, pudo ofrecer un mejor rendimiento. La puzolana se utilizó en forma natural, previo secado al aire.
The majority of experimental works covering shrinkage have been performed using concretes made of portland cements in general. The foregoing shows the necessity of conducting experimental studies aimed at achieving a qualitative and quantitative evaluation of a given cement from shrinkage wiewpoint. Hence this work endeavours to study the shrinkage behaviour of cements made from Chilean raw materials. Cements produced industrially and experimentally were employed for this purpose.

Experimentally produced cements differ from industrial ones in the mill type used to grind them, in the temperatures reached by the cement in the mill, and in the small amounts produced.

Preparation of raw materials as well as grinding of the experimental cements were carried out at the Pilot Plant of the Experimental Station, of IDIEM Institute, located in the Los Cerrillos district of Santiago.

\section{Raw Materials}

Clínker: Clinker used to make the experimental cements was supplied by two Chilean manufacturers that kindly collaborated in the carrying out of the present study.

The chemical composition of the clinkers is given in Table II.

The potential composition of the corresponding mineral phases is given in Table III.

Addition: The pozzolan used in this study came from the mineral deposits located in the Pudahuel district of Santiago.

Tables IV and $V$ give their chemical and physical properties, respectively.

Gypsum: The chemical composition of gypsum used to make the experimental cements is given in Table VI.

\section{Preparation of raw materials}

Grinding of the experimental cements was first performed by using a jaw crusher to the end of reducing the size of both the fragments of natural gypsum and the particles of clinker 3 to $20 \mathrm{~mm}$ in diameter. Thereafter a HARDINGE conical ball-mill having a complete air-classification system was used, and this machine was able to supply an improved yield on receiving smaller particles. The pozzolan was employed in its natural form after being air-dried. 
TABLA II

Composición química de los clínkeres A y $B$

\begin{tabular}{|c|c|c|}
\hline Componentes & Clínker A (\%) & Clínker B (\%) \\
\hline $\begin{array}{l}\text { Óxido de Silicio }\left(\mathrm{SiO}_{2}\right) \\
\text { Óxido de Aluminio }\left(\mathrm{Al}_{2} \mathrm{O}_{3}\right) \\
\text { Óxido Férrico }\left(\mathrm{Fe}_{2} \mathrm{O}_{3}\right) \\
\text { Pentóxido de Fósforo }\left(\mathrm{P}_{2} \mathrm{O}_{5}\right) \\
\text { Óxido de Titanio }\left(\mathrm{TiO}_{2}\right) \\
\text { Óxido de Manganeso }\left(\mathrm{Mn}_{2} \mathrm{O}_{3}\right) \\
\text { Óxido de Calcio }(\mathrm{CaO}) \\
\text { Óxido de Magnesio }(\mathrm{MgO}) \\
\text { Óxido de Sodio }\left(\mathrm{Na}_{2} \mathrm{O}\right) \\
\text { Óxido de Potasio }\left(\mathrm{K}_{2} \mathrm{O}\right) \\
\text { Óxido de Azufre }\left(\mathrm{SO}_{3}\right) \\
\text { Cal libre (CaO) } \\
\text { Pérdida por calcinación a } 950 \pm 50^{\circ} \mathrm{C} \\
\text { Residuo insoluble }\end{array}$ & $\begin{array}{r}19,18 \\
6,26 \\
3,09 \\
0,01 \\
0,50 \\
0,16 \\
64,60 \\
2,21 \\
1,25 \\
0,75 \\
1,36 \\
1,96 \\
0,64 \\
0,17\end{array}$ & $\begin{array}{r}22,15 \\
4,55 \\
2,98 \\
0,49 \\
0,22 \\
0,04 \\
66,15 \\
2,44 \\
0,11 \\
0,08 \\
0,74 \\
0,45 \\
1,57 \\
3,24\end{array}$ \\
\hline
\end{tabular}

TABLE II

Chemical composition of clinkers $A$ and $B$

\begin{tabular}{|c|c|c|}
\hline Components & Clinker A (\%) & Clinker B (\%) \\
\hline $\begin{array}{l}\text { Silicon oxide }\left(\mathrm{SiO}_{2}\right) \\
\text { Aluminium oxide }\left(\mathrm{Al}_{2} \mathrm{O}_{3}\right) \\
\text { Ferric oxide }\left(\mathrm{Fe}_{2} \mathrm{O}_{3}\right) \\
\text { Phosphor pentoxide }\left(\mathrm{P}_{2} \mathrm{O}_{5}\right) \\
\text { Titanium oxide }\left(\mathrm{TiO}_{2}\right) \\
\text { Manganese oxide }\left(\mathrm{Mn}_{2} \mathrm{O}_{3}\right) \\
\text { Calcium oxide }(\mathrm{CaO}) \\
\text { Magnesium oxide }(\mathrm{MgO}) \\
\text { Sodium oxide }\left(\mathrm{Na}_{2} \mathrm{O}\right) \\
\text { Potassium oxide }\left(\mathrm{K}_{2} \mathrm{O}\right) \\
\text { Sulphur oxide }\left(\mathrm{SO}_{3}\right) \\
\text { Free lime }(\mathrm{CaO}) \\
\text { Loss on ingnition at } 950 \pm 50^{\circ} \mathrm{C} \\
\text { Insoluble residue }\end{array}$ & $\begin{array}{r}19,18 \\
6,26 \\
3,09 \\
0,01 \\
0,50 \\
0,16 \\
64,60 \\
2,21 \\
1,25 \\
0,75 \\
1,36 \\
1,96 \\
0,64 \\
0,17\end{array}$ & $\begin{array}{r}22,15 \\
4,55 \\
2,98 \\
0,49 \\
0,22 \\
0,04 \\
66,15 \\
2,44 \\
0,11 \\
0,08 \\
0,74 \\
0,45 \\
1,57 \\
3,24\end{array}$ \\
\hline
\end{tabular}

TABLA III

Fases minerales potenciales de los clínkeres $A$ y $B$

\begin{tabular}{|l|c|c|}
\hline \multicolumn{1}{|c|}{ Fase } & Clínker A & Clínker B \\
\hline Silicato tricálcico $\left(C_{3} S\right), \%$ & 61 & 64 \\
Silicato dicálcico $\left(C_{2} S\right), \%$ & 12 & 15 \\
Aluminato tricálcico $\left(C_{3} A\right), \%$ & 12 & 7 \\
Ferroaluminato tetracálcico $\left(C_{4} A F\right), \%$ & 10 & 9 \\
\hline
\end{tabular}

TABLE III

Potential mineral phases of clinkers $A$ and $B$

\begin{tabular}{|c|c|c|}
\hline Fase & Clínker A & Clínker B \\
\hline $\begin{array}{l}\text { Tricalcium silicate }\left(C_{3} S\right), \% \\
\text { Dicalcium silicate }\left(C_{2} S\right), \% \\
\text { Tricalcium aluminate }\left(C_{3} A\right), \% \\
\text { Tetracalcium ferroaluminate }\left(C_{4} A F\right), \%\end{array}$ & $\begin{array}{l}61 \\
12 \\
12 \\
10\end{array}$ & $\begin{array}{r}64 \\
15 \\
7 \\
9\end{array}$ \\
\hline
\end{tabular}


TABLA IV

Composición química de la puzolana natural

\begin{tabular}{|l|c|}
\hline \multicolumn{1}{|c|}{ Componentes } & Cantidad, \% \\
\hline Sílice $\left(\mathrm{SiO}_{2}\right)$ & 68,00 \\
Óxido de Aluminio $\left(\mathrm{Al}_{2} \mathrm{O}_{3}\right)$ & 14,58 \\
Óxido Férrico $\left(\mathrm{Fe}_{2} \mathrm{O}_{3}\right)$ & 2,08 \\
Óxido de Magnesio $\left(\mathrm{MgO}^{\prime}\right)$ & 0,97 \\
Óxido de Calcio $\left(\mathrm{CaO}^{\circ}\right)$ & 2,55 \\
Trióxido de Azufre $\left(\mathrm{SO}_{3}\right)$ & 0,08 \\
Óxido de Sodio $\left(\mathrm{Na}_{2} \mathrm{O}\right)$ & 3,84 \\
Óxido de Potasio $\left(\mathrm{K}_{2} \mathrm{O}\right)$ & 3,70 \\
Cloruros $(\mathrm{Cl})$ & 0,01 \\
Pérdida por calcinación a $\left(950^{\circ} \mathrm{C}\right)$ & 4,26 \\
\hline
\end{tabular}

TABLA V

Propiedades físicas de la puzolana*

\begin{tabular}{|l|c|}
\hline \multicolumn{1}{|c|}{ Propiedades } & Valor \\
\hline Peso específico relativo & 2,41 \\
Densidad aparente $\left(\mathrm{kg} / \mathrm{dm}^{3}\right)$, suelta & 0,98 \\
\hline
\end{tabular}

- Puzolana bajo tamiz ASTM N.? 35.

TABLA VI

Composición química del yeso

\begin{tabular}{|l|r|}
\hline \multicolumn{1}{|c|}{ Componentes } & Cantidad, \% \\
\hline Sílice y materias insolubles & \\
$\left.(\mathrm{SiO})_{2}\right)$ & 0,42 \\
Óxido de Hierro y Aluminio & \\
$\left(\mathrm{Fe}_{2} \mathrm{O}_{3}+\mathrm{Al}_{2} \mathrm{O}_{3}\right)$ & 0,06 \\
Óxido de Calcio $(\mathrm{CaO})$ & 34,26 \\
Óxido de Magnesio $(\mathrm{MgO})$ & 0,36 \\
Trióxido de Azufre $\left(\mathrm{SO}_{3}\right)$ & 44,78 \\
Cloruro de Sodio $\left(\mathrm{NaCl}^{\prime}\right)$ & 0,11 \\
Agua libre & 0,02 \\
Agua combinada & 19,98 \\
Óxido de Potasio $\left(\mathrm{K}_{2} \mathrm{O}\right)$ & 0,01 \\
Óxido de Sodio $\left(\mathrm{Na}_{2} \mathrm{O}\right)$ & 0,02 \\
Óxido de Titanio $\left(\mathrm{TiO}_{2}\right)$ & 0,02 \\
\hline
\end{tabular}

\section{Dosificación}

Las materias primas se dosificaron en peso. En este sentido, a pesar de existir ecuaciones teóricas para dosificar la dosis óptima de yeso, por razones prácticas, se dejó constante su porcentaje en peso para cada tipo de clínker. Los valores elegidos para la fabricación de los cementos experimentales se encuentran en la tabla VII.
TABLE IV

Chemical composition of natural pozzolan

\begin{tabular}{|l|r|}
\hline \multicolumn{1}{|c|}{ Components } & Amount, \% \\
\hline Silica $\left(\mathrm{SiO}_{2}\right)$ & 68,00 \\
Aluminium oxide $\left(\mathrm{Al}_{2} \mathrm{O}_{3}\right)$ & 14,58 \\
Ferric oxide $\left(\mathrm{Fe}_{2} \mathrm{O}_{3}\right)$ & 2,08 \\
Magnesium oxide $(\mathrm{MgO})$ & 0,97 \\
Calcium oxide $(\mathrm{CaO})$ & 2,55 \\
Sulphur trioxide $\left(\mathrm{SO}_{3}\right)$ & 0,08 \\
Sodium oxide $\left(\mathrm{Na}_{2} \mathrm{O}\right)$ & 3,84 \\
Potasium oxide $\left(\mathrm{K}_{2} \mathrm{O}\right)$ & 3,70 \\
Chlorides $(\mathrm{Cl})$ & 0,01 \\
Loss on ignition $\left(950^{\circ} \mathrm{C}\right)$ & 4,26 \\
\hline
\end{tabular}

TABLE V

Physical properties of pozzolan*

\begin{tabular}{|l|c|}
\hline \multicolumn{1}{|c|}{ Properties } & Value \\
\hline Relative specific weight & 2,41 \\
Bulk density $\left(\mathrm{kg} / \mathrm{dm}^{3}\right.$ ), loose & 0,98 \\
\hline
\end{tabular}

- Pozzolan under ASTM sieve N.? 35.

TABLE VI

Chemical comoposition of gypsum

\begin{tabular}{|l|r|}
\hline \multicolumn{1}{|c|}{ Components } & Amount, \% \\
\hline Silica and insoluble substances & \\
$\left(\mathrm{SiO}_{2}\right)$ & 0,42 \\
Oxide of iron and aluminium & \\
$\left(\mathrm{Fe}_{2} \mathrm{O}_{3}+\mathrm{Al}_{2} \mathrm{O}_{3}\right)$ & 0,06 \\
Calcium oxide $(\mathrm{CaO})$ & 34,26 \\
Magnesium oxide $(\mathrm{MgO})$ & 0,36 \\
Sulphur trioxide $\left(\mathrm{SO}_{3}\right)$ & 44,78 \\
Sodium chloride $(\mathrm{NaCl})$ & 0,11 \\
Free water & 0,02 \\
Combined water & 19,98 \\
Potassium oxide $\left(\mathrm{K}_{2} \mathrm{O}\right)$ & 0,01 \\
Sodium oxide $\left(\mathrm{Na}_{2} \mathrm{O}\right)$ & 0,02 \\
Titanium oxide $\left(\mathrm{TiO}_{2}\right)$ & $<0,02$ \\
\hline
\end{tabular}

\section{Proportioning}

The raw materials were proportioned by weight. In this respect, despite the existence of theoretical equations for achieving the optimal proportioning of gypsum, practical reasons caused to leave constant its weight percent for every type of clinker. The values chosen for making the experimental cements are given in Table VII. 
TABLA VII

Dosificación de los cementos

\begin{tabular}{|c|c|c|c|c|c|c|c|}
\hline $\begin{array}{l}\text { Tipo de } \\
\text { Clínker }\end{array}$ & $\begin{array}{c}\text { Puzolana } \\
\text { (\%) }\end{array}$ & $\begin{array}{c}\text { Yeso } \\
\text { (\%) }\end{array}$ & $\begin{array}{c}\text { Clínker } \\
(\%)\end{array}$ & $\begin{array}{l}\text { Tipo de } \\
\text { clínker }\end{array}$ & $\begin{array}{c}\text { Puzolana } \\
\text { (\%) }\end{array}$ & $\begin{array}{c}\text { Yeso } \\
(\%)\end{array}$ & $\begin{array}{c}\text { Clinker } \\
(\%)\end{array}$ \\
\hline A & $\begin{array}{c}0 \\
10 \\
20 \\
30\end{array}$ & $\begin{array}{l}7 \\
7 \\
7 \\
7\end{array}$ & $\begin{array}{l}93 \\
83 \\
73 \\
63\end{array}$ & B & $\begin{array}{c}0 \\
10 \\
20 \\
30\end{array}$ & $\begin{array}{l}4 \\
4 \\
4 \\
4\end{array}$ & $\begin{array}{l}96 \\
86 \\
76 \\
66\end{array}$ \\
\hline
\end{tabular}

- TABle VII

Proportioning of the cements

\begin{tabular}{|c|c|c|c|c|c|c|c|}
\hline $\begin{array}{c}\text { Clinker } \\
\text { type }\end{array}$ & $\begin{array}{c}\text { Pozzolan } \\
(\%)\end{array}$ & $\begin{array}{c}\text { Gypsum } \\
(\%)\end{array}$ & $\begin{array}{c}\text { Clinker } \\
(\%)\end{array}$ & $\begin{array}{c}\text { Clinker } \\
\text { type }\end{array}$ & $\begin{array}{c}\text { Pozzolan } \\
(\%)\end{array}$ & $\begin{array}{c}\text { Gypsum } \\
\text { (\%) }\end{array}$ & $\begin{array}{c}\text { Clinker } \\
(\%)\end{array}$ \\
\hline$A$ & $\begin{array}{c}0 \\
10 \\
20 \\
30\end{array}$ & $\begin{array}{l}7 \\
7 \\
7 \\
7\end{array}$ & $\begin{array}{l}93 \\
83 \\
73 \\
63\end{array}$ & B & $\begin{array}{c}0 \\
10 \\
20 \\
30\end{array}$ & $\begin{array}{l}4 \\
4 \\
4 \\
4\end{array}$ & $\begin{array}{l}96 \\
86 \\
76 \\
66\end{array}$ \\
\hline
\end{tabular}

\section{Molienda conjunta}

Conocida la dosificación de cada una de las materias primas, se procedió a realizar la fabricación de los cementos experimentales de la siguiente manera: primeramente, se introdujo en la tolva de descarga del molino $15 \mathrm{~kg}$ de material preparado a base de clínker, puzolana y yeso con la dosificación señalada, luego, a medida que la tolva se iba desocupando, se le agregaban nuevas cargas. La finura de molienda se reguló con el clasificador de finos que posee el molino para tal efecto, obteniéndose, para cada dosificación, dos tipos de cemento: un cemento grueso (finura 1) y un cemento fino (finura 2).

La identificación de cada cemento experimental se realizó asignándoles un código, formado por una letra y tres dígitos. La letra indicaba el tipo de clínker utilizado, los dos primeros dígitos el porcentaje de adición y el último dígito la finura. La identificación de los cementos experimentales se encuentra en tabla VIII.

Al término de la fabricación de los cementos experimentales, éstos fueron homogeneizados y envasados en bolsas de polietileno $(10 \mathrm{~kg}$ de cemento $\mathrm{c} / \mathrm{u}$ ). Luego esas bolsas se introdujeron en tambores metálicos, que se almacenaron a temperatura entre 18 y $27^{\circ} \mathrm{C}$ y humedad relativa entre 40 y $70 \%$.

\section{Joint grinding}

Once known the proportion for every one of the raw materials the every fabrication of the experimental cements was undertaken as follows. First, $15 \mathrm{~kg}$ of material prepared using clinker, pozzolan and gypsum according to the indicated percentages were loaded in the feeding hopper of the HARDINGE mill. Thereafter, according as the feeding hoper was discharging its contents, new batches were loaded therein. Grinding fineness was regulated by means of the corresponding classifying system provided in the mill, thus obtaining two types of cement for every classification, namely: a coarse cement (fineness 1) and a fine cement (fineness 2).

Each experimental cement was identified by assigning to the same a code comprising one capital letter and three digits. The capital letter indicated the clinker type used, the first two digits indicated additive percentage, and the last digit indicated fineness. The identification of the experimental cements is given in Table VIII.

On completing the fabrication of the experimental cements these were homogenized and packaged in polyethylene bags (10 kg cement per bag). Then the bags were placed within metalic drums stored at a temperature between 18 and $27^{\circ} \mathrm{C}$ and with a relative humidity between 40 and $70 \%$. 
TABLA VIII

Identificación adoptada para los cementos experimentales

\begin{tabular}{|c|c|c|c|c|c|c|c|}
\hline Cemento & Clínker & $\begin{array}{c}\text { Puzolana } \\
(\%)\end{array}$ & Finura & Cemento & Clínker & $\begin{array}{c}\text { Puzolana } \\
(\%)\end{array}$ & Finura \\
\hline $\begin{array}{l}\text { A001 } \\
\text { A101 } \\
\text { A201 } \\
\text { A301 } \\
\text { A002 } \\
\text { A102 } \\
\text { A202 } \\
\text { A302 }\end{array}$ & A & $\begin{array}{c}0 \\
10 \\
20 \\
30 \\
0 \\
10 \\
20 \\
30\end{array}$ & $\begin{array}{l}1 \\
1 \\
1 \\
1 \\
2 \\
2 \\
2 \\
2\end{array}$ & $\begin{array}{l}\mathrm{B} 001 \\
\mathrm{~B} 101 \\
\mathrm{~B} 201 \\
\mathrm{~B} 301 \\
\mathrm{~B} 002 \\
\mathrm{~B} 102 \\
\mathrm{~B} 202 \\
\mathrm{~B} 302\end{array}$ & B & $\begin{array}{c}0 \\
10 \\
20 \\
30 \\
0 \\
10 \\
20 \\
30\end{array}$ & $\begin{array}{l}1 \\
1 \\
1 \\
1 \\
2 \\
2 \\
2 \\
2\end{array}$ \\
\hline
\end{tabular}

TABLE VIII

Identification adopted for the experimental cements

\begin{tabular}{|c|c|c|c|c|c|c|c|}
\hline Cement & Clinker & $\begin{array}{c}\text { Pozzolan } \\
(\%)\end{array}$ & Fineness & Cement & Clinker & $\begin{array}{c}\text { Pozzolan } \\
(\%)\end{array}$ & Fineness \\
\hline A001 & & 0 & 1 & $B 001$ & & 0 & 1 \\
A101 & & 10 & 1 & $B 101$ & & 10 & 1 \\
A201 & & 20 & 1 & $B 201$ & & 20 & 1 \\
A301 & A & 30 & 1 & B301 & B & 30 & 1 \\
A002 & & 0 & 2 & B002 & & 10 & 2 \\
A102 & & 2 & B102 & & 20 & 2 \\
A202 & & 20 & 2 & B202 & & 30 & 2 \\
A302 & & 30 & 2 & B302 & & \\
\hline
\end{tabular}

\section{Características de los cementos experimentales}

El análisis químico de los cementos experimentales, efectuados según la norma INN NCh 147. Of 69 , se presenta en tabla IX.

Las propiedades físicas de los cementos experimentales determinadas según normas $\mathrm{NCh}$ aparecen en tabla $X$.

Por su parte, los cementos comerciales que se utilizaron para estudiar la retracción de pastas y morteros de cemento, estaban constituidos con clínkeres que presentaban las fases potenciales según Bogue, que se indican en tabla XI.

\section{Ensayos de retracción}

Medir la retracción en pastas o morteros de cemento en estado fresco es un problema difícil de resolver. La principal dificultad radica en medir la variación de longitud de la probeta cuando el material es susceptible de deformarse, aun bajo la acción de una fuerza muy pequeña. Por ello,

\section{Characteristics of the experimental cements}

The chemical analysis of the experimental cements was carried out in keeping with Chilean Standard INN NCh 147. Of 69 and the corresponding results are given in Table IX.

The physical properties of the experimental cements determined in accordance with Chilean Standards are given en Table $X$.

On the other hand, the commercial cements used to study the shrinkage of cement pastes and mortars were constituted by clinkers that exhibited the potential phases after Bogue given in Table XI.

\section{Shrinkage tests}

The measurements of shrinkage of cement pastes or mortars in the fresh state is a problem difficult to solve. The principal difficulty lies in measuring the length of the specimen when the material is still able to be deformed through the action of some very small force. Hence it is necessary that 
TABLA IX

Análisis químico de los cementos experimentales

\begin{tabular}{|c|c|c|c|c|c|c|c|c|c|}
\hline $\begin{array}{c}\text { Cemen- } \\
\text { to }\end{array}$ & $\begin{array}{l}\text { P.x.C } \\
(\%)\end{array}$ & $\begin{array}{l}\text { R.I. } \\
\text { (\%) }\end{array}$ & $\begin{array}{l}\mathrm{SO}_{3} \\
(\%)\end{array}$ & $\begin{array}{c}\text { Mgo } \\
(\%)\end{array}$ & $\begin{array}{c}\text { Cemen- } \\
\text { to }\end{array}$ & $\begin{array}{c}\text { P.x.C } \\
\text { (\%) }\end{array}$ & $\begin{array}{l}\text { R.I. } \\
\text { (\%) }\end{array}$ & $\begin{array}{l}\mathrm{SO}_{3} \\
(\%)\end{array}$ & $\begin{array}{c}\mathrm{MgO} \\
(\%)\end{array}$ \\
\hline A001 & 2,03 & 0,51 & 3,61 & 2,03 & B001 & 1,53 & 0,32 & 2,55 & 1,97 \\
\hline A101 & 3,41 & 9,02 & 3,61 & - & B101 & 1,65 & 7,54 & 2,04 & - \\
\hline A201 & 2,92 & 15,89 & 3,65 & - & B201 & 2,09 & 16,22 & 2,26 & - \\
\hline A301 & 3,33 & 22,87 & 3,65 & - & B301 & 2,39 & 25,12 & 2,06 & - \\
\hline $\mathrm{A} 002$ & 2,13 & $1,94^{\star}$ & 3,59 & 1,86 & B002 & 1,76 & 1,34 & 1,98 & 1,78 \\
\hline A102 & 1,99 & 8,09 & 2,86 & - & B102 & 2,00 & 6,80 & 2,20 & - \\
\hline A202 & 2,92 & 15,23 & 3,35 & - & B202 & 2,63 & 17,40 & 2,10 & - \\
\hline A302 & 3,71 & 23,12 & 3,83 & - & $\mathrm{B} 302$ & 2,99 & 21,96 & 2,03 & - \\
\hline
\end{tabular}

- No cumple con la norma INN NCh 148 of 68.

TABLE IX

Chemical analysis of the experimental cements

\begin{tabular}{|c|c|c|c|c|c|c|c|c|c|}
\hline Cement & $\begin{array}{l}\text { Loss on } \\
\text { ignition } \\
(\%)\end{array}$ & $\begin{array}{l}\text { Inso- } \\
\text { luble } \\
\text { residue } \\
\text { (\%) }\end{array}$ & $\begin{array}{l}\mathrm{SO}_{3} \\
(\%)\end{array}$ & $\begin{array}{c}\text { MgO } \\
\text { (\%) }\end{array}$ & Cement & $\begin{array}{c}\text { Loss on } \\
\text { ignition } \\
(\%)\end{array}$ & $\begin{array}{l}\text { Inso- } \\
\text { luble } \\
\text { residue } \\
(\%)\end{array}$ & $\begin{array}{l}\mathrm{SO}_{3} \\
(\%)\end{array}$ & $\begin{array}{c}\text { Mgo } \\
(\%)\end{array}$ \\
\hline A001 & 2,03 & 0,51 & 3,61 & 2,03 & B001 & 1,53 & 0,32 & 2,55 & 1,97 \\
\hline A101 & 3,41 & 9,02 & 3,61 & - & B101 & 1,65 & 7,54 & 2,04 & - \\
\hline A201 & 2,92 & 15,89 & 3,65 & - & B201 & 2,09 & 16,22 & 2,26 & - \\
\hline А301 & 3,33 & 22,87 & 3,65 & - & B301 & 2,39 & 25,12 & 2,06 & - \\
\hline A002 & 2,13 & $1,94^{*}$ & 3,59 & 1,86 & B002 & 1,76 & 1,34 & 1,98 & 1,78 \\
\hline A102 & 1,99 & 8,09 & 2,86 & - & B102 & 2,00 & 6,80 & 2,20 & - \\
\hline A202 & 2,92 & 15,23 & 3,35 & - & B202 & 2,63 & 17,40 & 2,10 & - \\
\hline А302 & 3,71 & 23,12 & 3,83 & - & B302 & 2,99 & 21,96 & 2,03 & - \\
\hline
\end{tabular}

- It does not comply with Chilean Standard INN NCH 148 of 68.

es necesario que la probeta esté en un molde y el sistema de medición no ponga ninguna resistencia al desplazamiento. Muchos investigadores miden la variación de longitud siguiendo los movimientos de marcas colocadas sobre la cara superior (cara libre) de la probeta. Sin embargo, lo más representativo, es la variación de longitud de la probeta a nivel de su eje longitudinal de simetría, porque sobre la superficie expuesta actúa muy fuertemente el medio ambiente, especialmente para la primera retracción y, además, la composición de la capa superficial está siempre sobredosificada en agua y elementos finos y alli se alcanza más rápido el equilibrio de las temperaturas y de las tensiones de vapor que en el centro de la probeta. Por otra parte, al fondo de la probeta está expuesto a la acción del roce del molde que impide el libre desplazamiento del material.

El sistema de ensayo, diseñado e implementado en el Laboratorio de la Sección Aglomerantes del IDIEM, consistió en seguir los movimientos de topes metálicos situados en los extremos de un molde, que permanecian solidarios a la probeta de pasta de cemento o de mortero estudiados. the specimen be within some mould and that the measuring system cause no resistance to specimen displacement. Many investigators measure length variation by following the movements of certain marks located on the upper side (the free side) of the specimen. However, the most representative variation is the one that is occuring at the level of the longitudinal axis of symmetry of the specimen, because the ambient medium is strongly acting on the exposed surface of the specimen and, in addition, the composition of the superficial layer of material is always over-proportioned as regards water and fine elements; moreover, temperatures and steam-pressure equilibriums are reached in this layer more quickly than in specimen center. On the other hand, specimen bottom is exposed to the action of the friction with the mould, which prevents the free displacement of the material.

The testing system designed and implemented at the Laboratory of the IDIEM Department of Agglomerants consisted in following the movements of metalic plugs provided at the ends of a mould and that remained solidarily joined to the specimen made of the cement or mortar paste studied. 
TABLA $X$

Propiedades físicas y mecánicas de los cementos experimentales

\begin{tabular}{|c|c|c|c|c|c|c|c|c|c|c|c|}
\hline \multirow[b]{2}{*}{ Cmto. } & \multirow{2}{*}{$\begin{array}{l}\text { C.N. } \\
\text { (\%) }\end{array}$} & \multicolumn{2}{|c|}{ Fraguado } & \multirow{2}{*}{$\begin{array}{l}\text { Peso } \\
\text { espec. }\end{array}$} & \multirow{2}{*}{$\begin{array}{l}\text { S.E. } \\
\mathrm{cm}^{2} / \mathrm{g}\end{array}$} & \multirow{2}{*}{ Cmto. } & \multirow{2}{*}{$\begin{array}{l}\text { C.N. } \\
(\%)\end{array}$} & \multicolumn{2}{|c|}{ Fraguado } & \multirow{2}{*}{$\begin{array}{l}\text { Peso } \\
\text { espec. }\end{array}$} & \multirow{2}{*}{$\begin{array}{l}\text { S.E. } \\
\mathrm{cm}^{2} / \mathrm{g}\end{array}$} \\
\hline & & $\begin{array}{l}\text { Inic. } \\
\text { (h:m) }\end{array}$ & $\begin{array}{l}\text { Fin } \\
(\mathrm{h}: \mathrm{m})\end{array}$ & & & & & $\begin{array}{l}\text { Inic. } \\
\text { (h:m) }\end{array}$ & $\begin{array}{l}\text { Fin } \\
\text { (h:m) }\end{array}$ & & \\
\hline A001 & 26,50 & $2: 30$ & 3:20 & 3,092 & 3050 & B001 & 26,00 & $3: 40$ & 4:40 & 3,153 & 3050 \\
\hline A101 & 27,00 & $2: 50$ & $3: 40$ & 3,016 & 3400 & B101 & 27,00 & $3: 50$ & $4: 40$ & 3,070 & 3200 \\
\hline A201 & 28,50 & $2: 30$ & 3:20 & 2,914 & 3500 & B201 & 28,00 & $3: 20$ & 4:20 & 2,984 & 2750 \\
\hline A301 & 30,25 & 3:10 & $3: 50$ & 2,855 & 3250 & B301 & 28,75 & $3: 40$ & $4: 40$ & 2,916 & 2850 \\
\hline $\mathrm{A} 002$ & 32,50 & $2: 00$ & 3:20 & 3,092 & 4450 & $\mathrm{~B} 002$ & 33,00 & $3: 10$ & $4: 10$ & 3,122 & 5100 \\
\hline A102 & 30,00 & $2: 20$ & $3: 30$ & 3,019 & 3950 & B102 & 32,75 & $2: 50$ & $3: 40$ & 3,040 & 5800 \\
\hline A202 & 35,50 & $2: 20$ & 3:20 & 2,924 & 5700 & B202 & 34,25 & $2: 30$ & 4:10 & 2,940 & 6200 \\
\hline A302 & 33,50 & $2: 40$ & $3: 30$ & 2,832 & 5850 & B302 & 30,50 & $3: 00$ & $4: 00$ & 2,988 & 5750 \\
\hline
\end{tabular}

TABLE $X$

Physical and mechanical properties of the experimental cements

\begin{tabular}{|c|c|c|c|c|c|c|c|c|c|c|c|}
\hline \multirow{2}{*}{ Cement } & \multirow{2}{*}{$\begin{array}{c}\text { Normal } \\
\text { consis- } \\
\text { tency } \\
(\%)\end{array}$} & \multicolumn{2}{|c|}{ Setting } & \multirow{2}{*}{$\begin{array}{c}\text { Specific } \\
\text { weight }\end{array}$} & \multirow{2}{*}{$\begin{array}{l}\text { Specific } \\
\text { surface } \\
\left(\mathrm{cm}^{2} / \mathrm{g}\right)\end{array}$} & \multirow{2}{*}{ Cement } & \multirow{2}{*}{$\begin{array}{c}\text { Normal } \\
\text { consis- } \\
\text { tency } \\
(\%)\end{array}$} & \multicolumn{2}{|c|}{ Setting } & \multirow{2}{*}{$\begin{array}{c}\text { Specific } \\
\text { weight }\end{array}$} & \multirow{2}{*}{$\begin{array}{l}\text { Specific } \\
\text { surface } \\
\left(\mathrm{cm}^{2} / \mathrm{g}\right)\end{array}$} \\
\hline & & $\begin{array}{l}\text { Start } \\
(h: m)\end{array}$ & $\begin{array}{l}\text { End } \\
(h: m)\end{array}$ & & & & & $\begin{array}{l}\text { Start } \\
(h: m)\end{array}$ & $\begin{array}{l}\text { End } \\
(h: m)\end{array}$ & & \\
\hline A001 & 26,50 & $2: 30$ & $3: 20$ & 3,092 & 3050 & B001 & 26,00 & 3:40 & $4: 40$ & 3,153 & 3050 \\
\hline A101 & 27,00 & $2: 50$ & $3: 40$ & 3,016 & 3400 & B101 & 27,00 & 3:50 & 4:40 & 3,070 & 3200 \\
\hline A.201 & 28,50 & $2: 30$ & $3: 20$ & 2,914 & 3500 & $\mathrm{~B} 201$ & 28,00 & $3: 20$ & 4:20 & 2,984 & 2750 \\
\hline A301 & 30,25 & $3: 10$ & $3: 50$ & 2,855 & 3250 & $\mathrm{~B} 301$ & 28,75 & $3: 40$ & $4: 40$ & 2,916 & 2850 \\
\hline $\mathrm{A} 002$ & 32,50 & $2: 00$ & $3: 20$ & 3,092 & 4450 & B002 & 33,00 & $3: 10$ & $4: 10$ & 3,122 & 5100 \\
\hline A102 & 30,00 & $2: 20$ & $3: 30$ & 3,019 & 3950 & B102 & 32,75 & $2: 50$ & $3: 40$ & 3,040 & 5800 \\
\hline A202 & 35,50 & $2: 20$ & $3: 20$ & 2,924 & 5700 & B202 & 34,25 & $2: 30$ & $4: 10$ & 2,940 & 6200 \\
\hline A302 & 33,50 & $2: 40$ & $3: 30$ & 2,832 & 5850 & $\mathrm{~B} 302$ & 30,50 & $3: 00$ & $4: 00$ & 2,988 & 5750 \\
\hline
\end{tabular}

TABLA XI

Fases minerales potenciales del clínker de los cementos comerciales

\begin{tabular}{|c|c|c|c|c|}
\hline \multirow{2}{*}{ Fase } & \multicolumn{4}{|c|}{ Composición, \% } \\
\hline & $\underset{\mathrm{X}}{\text { Cemento }}$ & $\begin{array}{c}\text { Cemento } \\
Y\end{array}$ & $\begin{array}{c}\text { Cemento } \\
\mathbf{Z}\end{array}$ & $\begin{array}{c}\text { Cemento } \\
\text { W }\end{array}$ \\
\hline $\begin{array}{l}\text { Silicato tricálcico }\left(C_{3} S\right), \% \\
\text { Silicato dicálcico }\left(C_{2} S\right), \% \\
\text { Aluminato tricálcico }\left(C_{3} A\right), \% \\
\text { Ferroaluminato tetracálcico }\left(C_{4} A F\right), \%\end{array}$ & $\begin{array}{r}61 \\
17 \\
6 \\
12\end{array}$ & $\begin{array}{l}61 \\
13 \\
12 \\
10\end{array}$ & $\begin{array}{r}64 \\
17 \\
5 \\
10\end{array}$ & $\begin{array}{r}54 \\
22 \\
12 \\
8\end{array}$ \\
\hline
\end{tabular}

TABLE XI

Potential mineral phases exhibited by the clinker of commercial cements

\begin{tabular}{|c|c|c|c|c|}
\hline \multirow{2}{*}{ Phase } & \multicolumn{4}{|c|}{ Composition, \% } \\
\hline & $\begin{array}{c}\text { Cement } \\
\mathrm{X}\end{array}$ & $\begin{array}{c}\text { Cement } \\
Y\end{array}$ & $\begin{array}{c}\text { Cement } \\
\mathbf{Z}\end{array}$ & $\begin{array}{c}\text { Cement } \\
\text { W }\end{array}$ \\
\hline $\begin{array}{l}\text { Tricalcium silicate }\left(\mathrm{C}_{3} \mathrm{~S}\right), \% \\
\text { Dicalcium silicate }\left(\mathrm{C}_{2} \mathrm{~S}\right), \% \\
\text { Tricalcium aluminate }\left(\mathrm{C}_{3} \mathrm{~A}\right), \% \\
\text { Tetracalcium ferroaluminate }\left(\mathrm{C}_{4} \mathrm{AF}\right), \%\end{array}$ & $\begin{array}{r}61 \\
17 \\
6 \\
12\end{array}$ & $\begin{array}{l}61 \\
13 \\
12 \\
10\end{array}$ & $\begin{array}{r}64 \\
17 \\
5 \\
10\end{array}$ & $\begin{array}{r}54 \\
22 \\
12 \\
8\end{array}$ \\
\hline
\end{tabular}




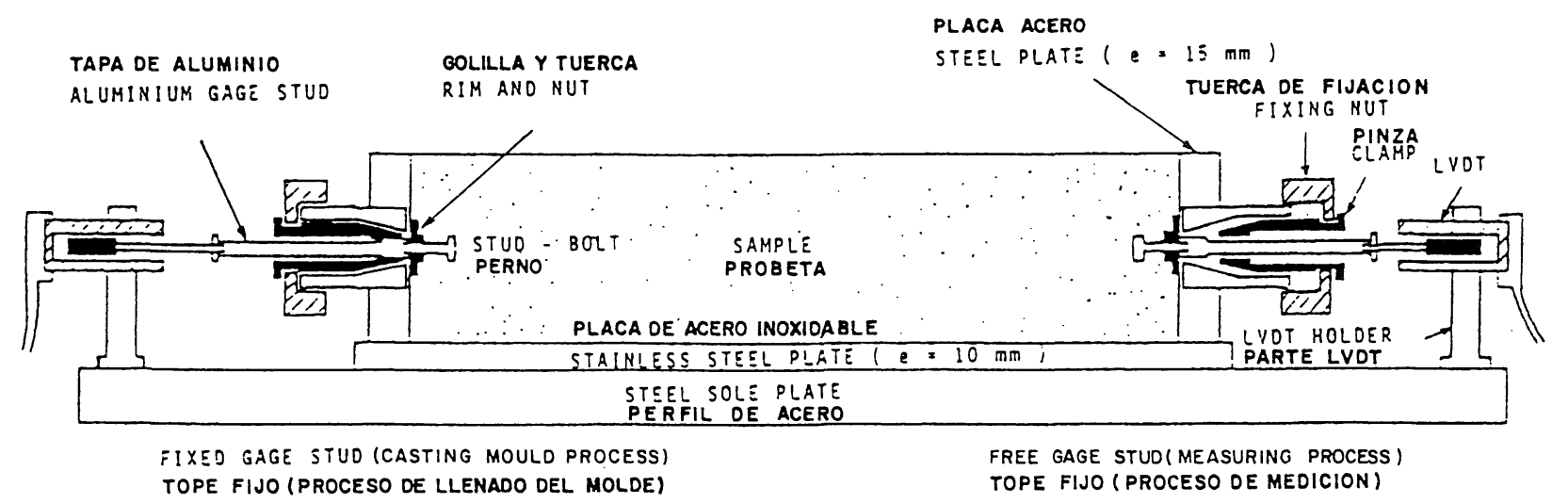

Fig. 7.-Esquema del sistema de medición.

Fig. 7.-Set-up of the measuring system.

Se confeccionaron para ello dos moldes de $7 \times 7$ $x 28 \mathrm{~cm}$, con placas laterales y base de acero inoxidable de $10 \mathrm{~mm}$ de espesor. Las placas confeccionadas en acero corriente de $15 \mathrm{~mm}$ de espesor, estaban provistas, en el centro, de un orificio de $8 \mathrm{~mm}$ de diámetro por el cual pasaba la parte posterior del tope. Cada tope pesaba $10 \mathrm{~g} \mathrm{y}$ estaba constituido por un cilindro hueco de aluminio al que se atornillaba, en uno de sus extremos, un perno de acero con una golilla y una tuerca. El otro extremo del cilindro permitía atornillar el émbolo del sensor electromagnético (Fig. 7).

Al finalizar el ensayo se recuperaba el cilindro de aluminio y el perno, cuya longitud de anclaje era de $1,5 \mathrm{~cm}$ y quedaba solidario a la probeta.

La totalidad del equipo estaba ubicada en una sala especialmente acondicionada con una temperatura de $20 \pm 1^{\circ} \mathrm{C}$ y una humedad relativa de $50 \pm 5 \%$.

El sistema descrito permite que a todo desplazamiento de los topes corresponda una intensidad de corriente susceptible de ser captada por un equipo registrador.

La base del sistema está en un sofisticado dispositivo de fijación que permite mantener rígidamente el tope durante el proceso de llenado del molde con la pasta o mortero de cemento y, mientras, se conecta el émbolo del sensor electromagnético. En seguida, cuando el montaje del ensayo está terminado, permite soltar el tope sin desplazamiento accidental de éste (Fig. 7). Pese a todo, inevitablemente en el momento de su liberación, el tope se separaba ligeramente de la pared del molde. Este movimiento parásito, siendo instantáneo, no podía ser confundido con una deformación de la pasta y daba al dispositivo de medida la posibilidad de registrar los ligeros hinchamientos que se producían a veces en el curso de la primeras horas siguientes al mezclado de la pasta.
To this end, two $7 \times 7 \times 28 \mathrm{~cm}$ moulds with side plates and a $10 \mathrm{~mm}$ thick base of stainless steel, were manufactured. The plates, made of $15 \mathrm{~mm}$ thick common steel, included a central orifice $8 \mathrm{~mm}$ in diameter, through which the rear portion of the plug was passing. Each plug weighed 10 grams and it was constituted by a hollow aluminium-cylinder of which one end carried a steel bolt with a washer and a nut. The other end of the cylinder allowed to screw therein the plunger of the electromagnetic sensor (Figure 7).

On completion of the test the aluminium cylinder was reconvered, and the bolt -whose anchorage length measured $1.5 \mathrm{~cm}$ - remained solidarily joined to the test specimen.

The whole equipment was located in a speciallyprepared room with a temperature of $20 \pm 1^{\circ} \mathrm{C}$ and $50 \pm 5 \%$ relative humidity.

The above-described system allows that whatever displacement of the plugs will produce an alectric-current intensity detectable by means of a recording equipment.

The basis of the system is a sophisticated holding-device that permits to rigidly hold the plug while filling the mould with the cement paste or mortar and connecting the electromagnetic-sensor plunger. Thereafter, on completion of such test-adjustment said device allows to release the plug without causing any accidental displacement thereof (Figure 7). Despite the foregoing, at the moment of releasing the plug this element separated itself from mould wall. As this parasitic movement was instantaneous, it could not be confused with some paste-deformation, and it supplied the possibility of using the measuring device to the end of recording the light swellings that were sometimes produced during the first hours which followed paste-mixing. 


\section{Dosificaciones}

La dosificación de los morteros fue en peso de una parte de cemento, tres partes de arena normal perfectamente seca y media parte de agua (razón $A C=0,50$ ). Las pastas, por su parte, se dosificaron con cantidades de cemento y agua necesarias para que la pasta pura adquiriera una "consistencia normal".

\section{Confección de pastas y morteros}

Los equipos y el procedimiento empleados en la confección de la pasta de cemento o del mortero estuvieron conforme a lo indicado por normas NCh.

Para la confección de morteros y pastas puras de cemento, se utilizó: agua potable que se mantuvo almacenada en un recipiente a temperatura constante, cementos existentes en el mercado nacional, cementos obtenidos en forma experimental y arena normal de San Sebastián para la confección de los morteros.

\section{ANÁLISIS DE RESULTADOS}

Las figuras $8,9,10$ y 11 muestran las retracciones registradas en los ensayos para pastas confeccionadas con cementos comerciales y para pastas y morteros confeccionadas con los cementos experimentales de este trabajo. Se observa en las curvas de deformación que para cada tipo de cemento corresponde un aspecto característico, fácilmente identificable, atribuible sin duda a la composición química del clínker en primer lugar, a la finura en segundo lugar $y$, luego, a las adiciones diversas.

En la tabla XII se presentan las principales características determinadas en los ensayos de retracción con pastas de cementos comerciales.

En la tabla XIII se presentan las principales características determinadas en los ensayos de retracción con pastas de cemento experimentales.

Para estudiar el efecto de las distintas variables aquí consideradas es preciso buscar sus correlaciones con la deformación. Así, por ejemplo, la Fig. 12 confirma que, en condiciones isotérmicas, cuanto mayor es la superficie específica, mayor es el valor máximo de la primera retracción y, también, mayor es su velocidad. La Fig. 13, a su vez, muestra que la primera retracción aumenta cuando la compactación es mayor. Esta aparente contradicción puede tal vez ser producto de la reducción de la razón agua cemento por efecto del agua exudada durante el vibrado.

\section{Proportioning}

Mortar proportioning was by weigth, using one part of cement, three parts of normal sand perfectly $d r y$, and half part of water $(w / c=0.50)$. On the other hand, the pastes were proportioned using the cement and water amounts required to impart a "normal consistency" to the neat paste.

\section{Preparation of the pastes and mortars}

The equipments and procedures employed in the preparation of cement paste or mortar were in accordance with the provisions of Chilean Standards NCh.

The preparation of mortars and neat pastes of cement was carried out using the following components: drinking water that was kept stored in a recipient at constant temperature; cements available on Chilean market; cements experimentally produced; and normal sand from San Sebastian for preparing the mortars.

\section{ANALYSIS OF THE RESULTS}

Figures 8, 9, 10 and 11 show the shrinkages recorded through the tests concerning the pastes made from commercial cements and the pastes and mortars made from the experimental cements of this work. The deformation curves allow to observe that each type of cement is associated with a characteristic aspect easily identifiable and doubtless due to the chemical composition of clinker in the first place, to fineness in the second place, and to the sundry additions in the third place.

Table XII gives the principal characteristics determined through the shrinkage tests made on commercial-cement pastes.

Table XIII gives the princial characteristics determined through the shrinkage tests made on pastes of experimental cements.

The study of the effect of the diverse variables considered herein requires investigating their correlations with deformation. Thus, for instance, Figure 12 confirms that, in isothermal conditions, the larger the specific surface the higher the maximum value of the first shrinkage, and also the higher its velocity. On the other hand, Figure 13 shows that the first shrinkage increases with increasing compaction. This apparent contradiction might be due to the reduction in water/cement ratio as a result of water-exudation during the vibration step. 


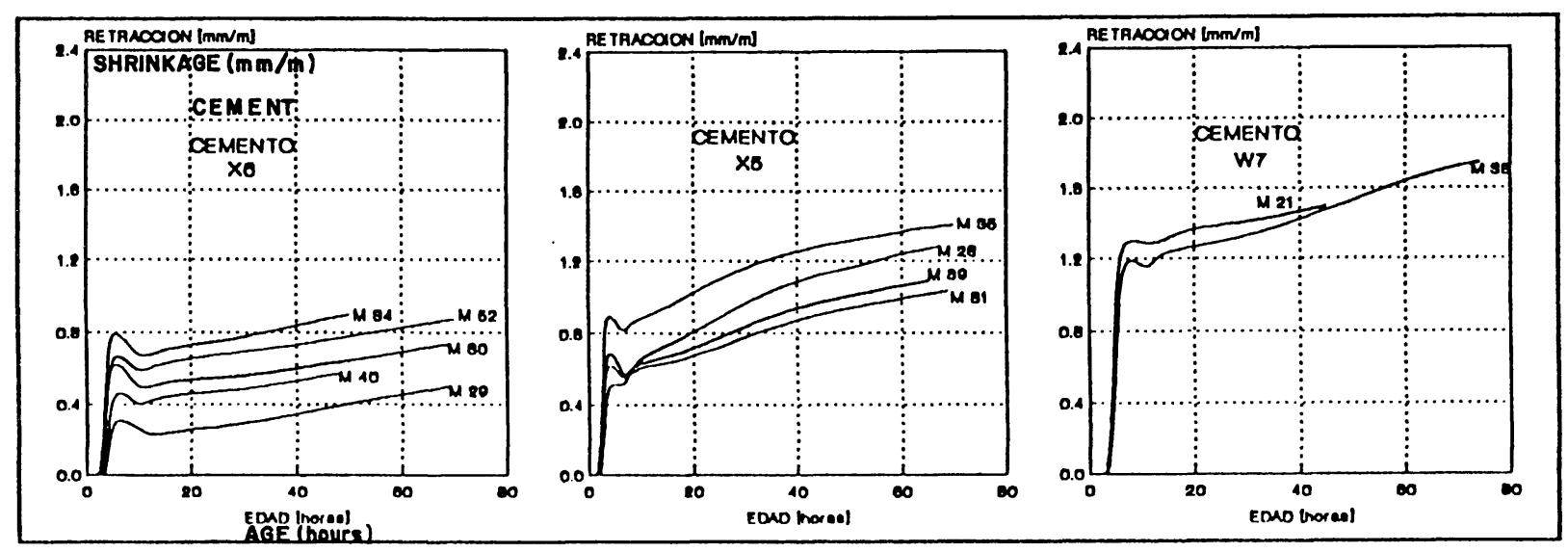

Fig. 8. - Curvas de retracción registradas con pastas de cemento $X$ y W.

Fig. 8. - Shrinkage curves recorded using cement pastes $X$ and $W$.

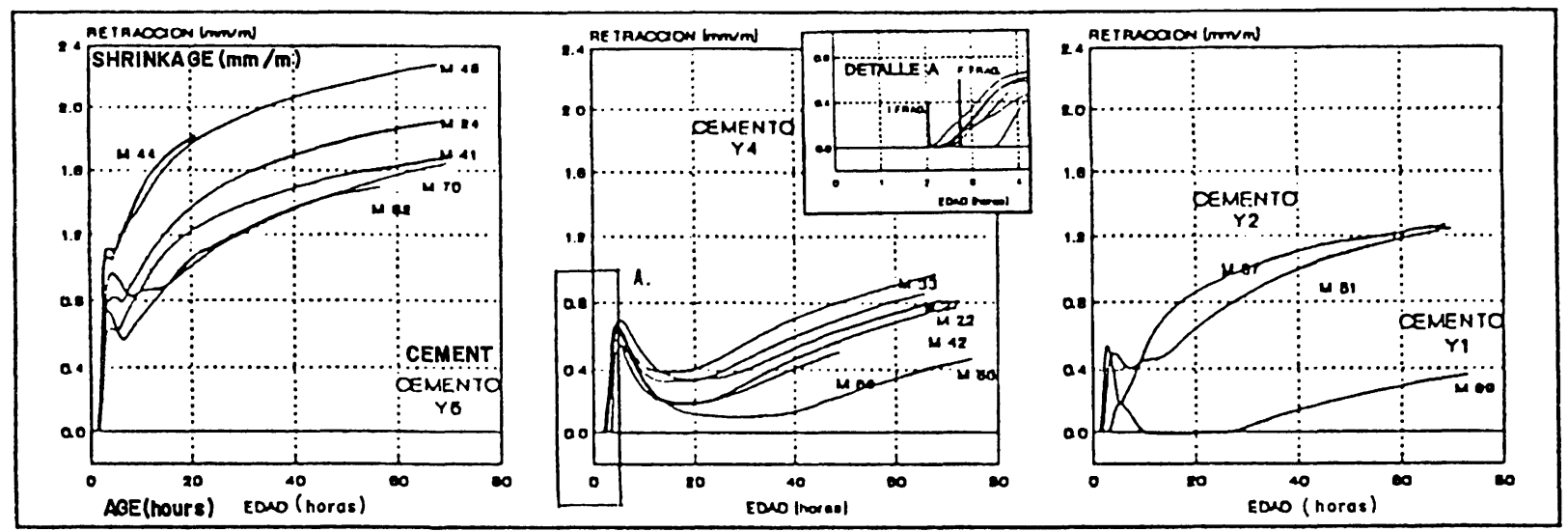

NOTA: El gráfico con curvas de retracción del cemento Y4 muestra, en detalle $A$, que la primera retracción sigue desarrollándose aun después del fin de fraguado en las seis muestras representadas, con riesgo de fisuración de la pasta.
NOTE: The graph plotting shrinkage-curves Y4 shows through Detail A that even afther setting-completion the first shrinkage continues developing in the six samples represented, with a corresponding risk of paste-fissuration.

Fig. 9.-Curvas de retracción registradas con pastas de cemento $Y$.

Fig. 9.-Shrinkage curves recorded using cement pastes $Y$.

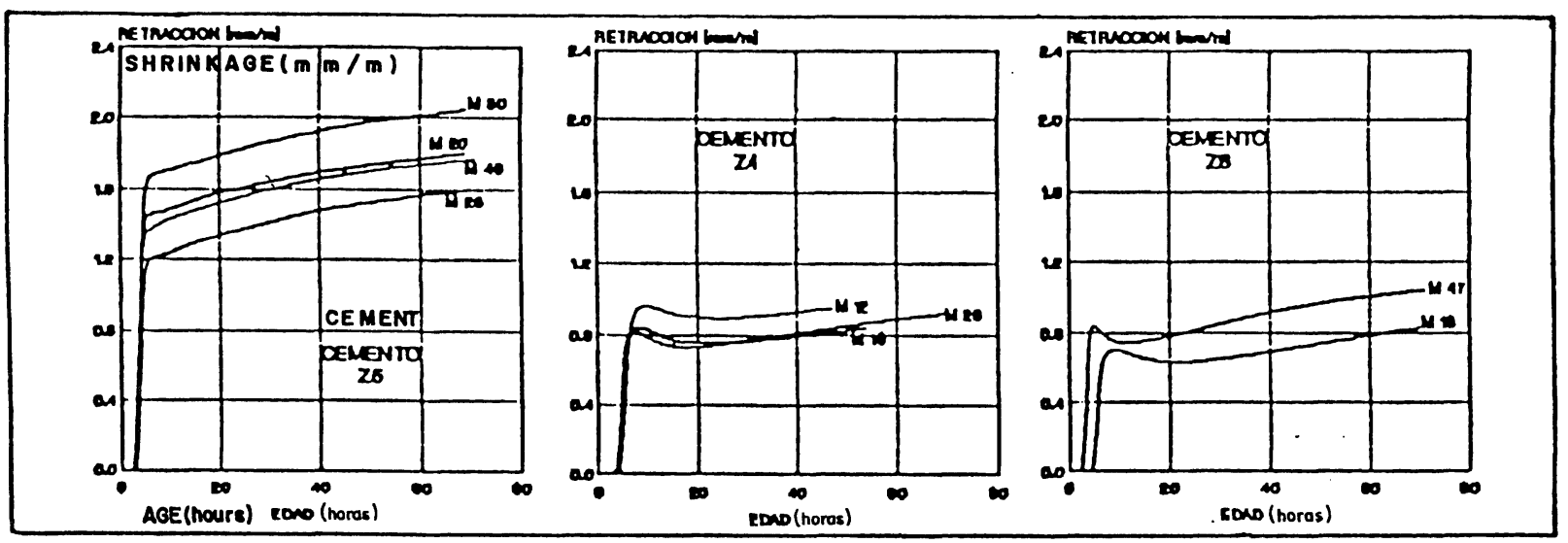

Fig. 10.-Curvas de retracción registradas con pastas de cemento $Z$.

Fig. 10. Shrinkage curves recorded using cement pastes $Z$. 

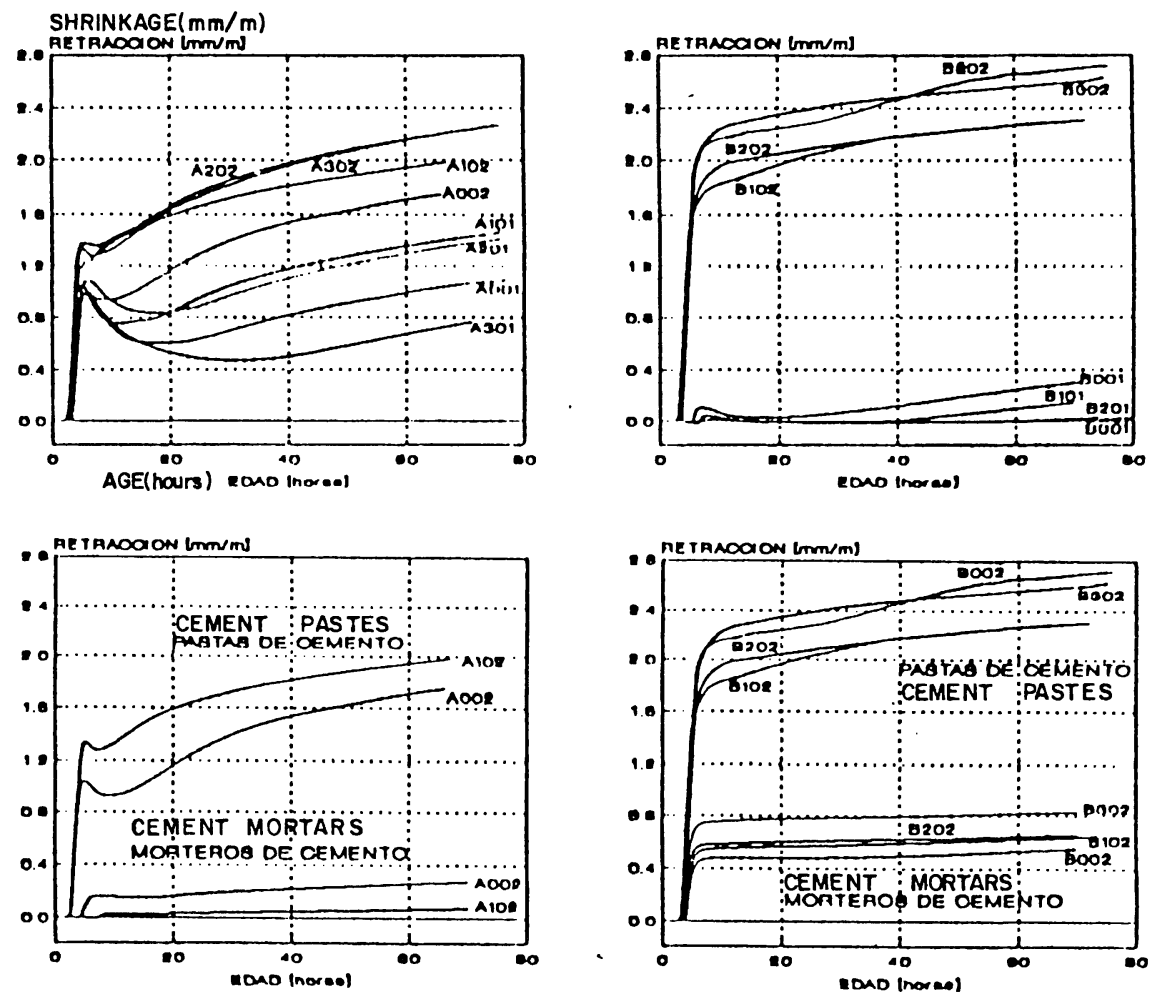

Fig. 11.-Curvas de retracción registradas con pastas y morteros de cemento experimental A y B.

Fig. 11.-Shrinkage curves recorded using pastes and mortars of experimental cement $\boldsymbol{A}$ and $B$.

TABLA XII

Resultados de ensayos con cementos comerciales

\begin{tabular}{|c|c|c|c|c|c|c|c|}
\hline Cemento & $\begin{array}{c}\text { S.E. } \\
\left(\mathbf{c m}^{2} / \mathbf{g}\right)\end{array}$ & $\begin{array}{c}\mathbf{S O}_{\mathbf{3}} \\
(\%)\end{array}$ & $\begin{array}{c}\mathbf{S O}_{\mathbf{3}} / \mathbf{C}_{\mathbf{3}} \mathbf{A} \\
(\%)\end{array}$ & $\begin{array}{c}\text { Hin. Máx. } \\
(\mathbf{m m} / \mathbf{m})\end{array}$ & $\begin{array}{c}\text { D. Hin. } \\
(\mathbf{h}: \mathbf{m})\end{array}$ & $\begin{array}{c}\text { V. Máx. 2R } \\
(\boldsymbol{\mu} \mathbf{m} / \mathbf{m} / \mathbf{h})\end{array}$ & $\begin{array}{c}\text { E. V. Máx. } \\
\mathbf{2 R}(\mathbf{h : m})\end{array}$ \\
\hline X5 & 4000 & 2,33 & 0,47 & 0,079 & $4: 05$ & 40 & $10: 21$ \\
X6 & 4000 & 1,96 & 0,51 & 0,126 & $6: 13$ & 11 & $29: 30$ \\
Y1 & 2600 & 3,60 & 0,36 & 0,194 & $13: 37$ & 14 & $29: 30$ \\
Y2 & 3600 & 2,53 & 0,26 & 0,227 & $2: 53$ & 72 & $12: 30$ \\
Y4 & 3800 & 2,70 & 0,41 & 0,403 & $20: 28$ & 15 & $36: 30$ \\
Y5 & 4700 & 3,18 & 0,38 & 0,070 & $1: 58$ & 100 & $7: 04$ \\
Z3 & 3500 & 2,09 & 0,52 & 0,076 & $11: 04$ & 8 & $30: 30$ \\
Z4 & 4250 & 2,25 & 0,73 & 0,080 & $15: 25$ & 5 & $32: 30$ \\
Z5 & 4900 & 2,03 & 0,58 & - & - & 16 & $10: 23$ \\
W7 & 4000 & 1,80 & 0,15 & 0,026 & $2: 45$ & 23 & $8: 20$ \\
\hline
\end{tabular}

TABLE XII

Results of tests using commercial cements

\begin{tabular}{|c|c|c|c|c|c|c|c|}
\hline Cement & $\begin{array}{l}\text { Specific } \\
\text { surface } \\
\left(\mathrm{cm}^{2} / \mathrm{g}\right)\end{array}$ & $\begin{array}{l}\mathrm{SO}_{3} \\
(\%)\end{array}$ & $\begin{array}{c}\mathrm{SO}_{3} / \mathrm{C}_{3} \mathrm{~A} \\
(\%)\end{array}$ & $\begin{array}{c}\text { Maximun } \\
\text { swelling } \\
\text { (mm/m) }\end{array}$ & $\begin{array}{c}\text { Swelling } \\
\text { duration } \\
(\mathrm{h}: \mathrm{m})\end{array}$ & $\begin{array}{c}\text { Max. V. 2S } \\
(\mu \mathrm{m} / \mathrm{m} / \mathrm{h})\end{array}$ & $\begin{array}{c}\text { Age Max. } \\
\text { V. 2S } \\
\text { (h:m) }\end{array}$ \\
\hline$\times 5$ & 4000 & 2,33 & 0,47 & 0,079 & $4: 05$ & 40 & $10: 21$ \\
\hline$X 6$ & 4000 & 1,96 & 0,51 & 0,126 & $6: 13$ & 11 & $29: 30$ \\
\hline$Y_{1}$ & 2600 & 3,60 & 0,36 & 0,194 & $13: 37$ & 14 & $29: 30$ \\
\hline Y2 & 3600 & 2,53 & 0,26 & 0,227 & $2: 53$ & 72 & $12: 30$ \\
\hline Y4 & 3800 & 2,70 & 0,41 & 0,403 & $20: 28$ & 15 & $36: 30$ \\
\hline Y5 & 4700 & 3,18 & 0,38 & 0,070 & $1: 58$ & 100 & 7:04 \\
\hline $\mathrm{Z3}$ & 3500 & 2,09 & 0,52 & 0,076 & $11: 04$ & 8 & $30: 30$ \\
\hline $\mathrm{Z4}$ & 4250 & 2,25 & 0,73 & 0,080 & $15: 25$ & 5 & $32: 30$ \\
\hline $\mathrm{Z5}$ & 4900 & 2,03 & 0,58 & - & - & 16 & $10: 23$ \\
\hline W7 & 4000 & 1,80 & 0,15 & 0,026 & $2: 45$ & 23 & $8: 20$ \\
\hline
\end{tabular}


TABLA XIII

Resultados de ensayos con cementos experimentales

\begin{tabular}{|c|c|c|c|c|c|c|c|}
\hline Cemento & $\begin{array}{c}\text { S.E. } \\
\left(\mathbf{c m}^{2} / \mathbf{g}\right)\end{array}$ & $\begin{array}{c}\mathbf{S O}_{3} \\
(\%)\end{array}$ & $\begin{array}{c}\mathbf{S O}_{\mathbf{3}} / \mathbf{C}_{3} \mathbf{A} \\
(\%)\end{array}$ & $\begin{array}{c}\text { Hin. Máx. } \\
(\mathbf{m m} / \mathbf{m})\end{array}$ & $\begin{array}{c}\text { D. Hin. } \\
(\mathbf{h}: \mathbf{m})\end{array}$ & $\begin{array}{c}\text { V. Máx. 2R } \\
(\boldsymbol{\mu} \mathbf{m} / \mathbf{m} / \mathbf{h})\end{array}$ & $\begin{array}{c}\text { E. V. Máx. } \\
\mathbf{2 R}(\mathbf{h}: \mathbf{m})\end{array}$ \\
\hline A001 & 3050 & 3,61 & 0,34 & 0,388 & $14: 07$ & 14 & $28: 30$ \\
A101 & 3400 & 3,61 & 0,38 & 0,220 & $5: 37$ & 22 & $21: 30$ \\
A201 & 3500 & 3,65 & 0,44 & 0,250 & $11: 52$ & 17 & $28: 30$ \\
A301 & 3250 & 3,65 & 0,51 & 0,493 & $26: 00$ & 10 & $42: 30$ \\
A002 & 4450 & 3,59 & 0,34 & 0,109 & $4: 45$ & 30 & $19: 30$ \\
A102 & 3950 & 2,86 & 0,30 & 0,060 & $1: 45$ & 40 & $9: 38$ \\
A202 & 5700 & 3,35 & 0,40 & - & - & 96 & $6: 56$ \\
A302 & 5850 & 3,83 & 0,54 & 0,016 & $1: 30$ & 32 & $8: 38$ \\
B001 & 3050 & 2,55 & 0,38 & 0,076 & $13: 35$ & 8 & $38: 30$ \\
B101 & 3200 & 2,04 & 0,34 & 0,063 & $13: 35$ & 6 & $42: 30$ \\
B201 & 2750 & 2,26 & 0,42 & 0,069 & $34: 00$ & 4 & $71: 30$ \\
B301 & 2850 & 2,06 & 0,45 & 0,031 & $19: 35$ & 3 & $71: 30$ \\
B002 & 5100 & 1,98 & 0,29 & - & - & 16 & $33: 30$ \\
B102 & 5800 & 2,20 & 0,36 & - & - & 8 & $16: 30$ \\
B202 & 6200 & 2,10 & 0,39 & - & - & 12 & $17: 30$ \\
B302 & 5750 & 2,02 & 0,44 & - & - & 16 & $17: 30$ \\
\hline
\end{tabular}

TABLE XIII

Results of tests using experimental cements

\begin{tabular}{|c|c|c|c|c|c|c|c|}
\hline Cement & $\begin{array}{c}\text { Specific } \\
\text { surface } \\
\left(\mathrm{cm}^{2} / \mathrm{g}\right)\end{array}$ & $\begin{array}{l}\mathrm{SO}_{3} \\
(\%)\end{array}$ & $\begin{array}{c}\mathrm{SO}_{3} / \mathrm{C}_{3} \mathrm{~A} \\
(\%)\end{array}$ & $\begin{array}{c}\text { Maximun } \\
\text { swelling } \\
(\mathrm{mm} / \mathrm{m})\end{array}$ & $\begin{array}{c}\text { Swelling } \\
\text { duration } \\
\text { (h:m) }\end{array}$ & $\begin{array}{c}\text { Max. V. } 2 S \\
(\mu \mathrm{m} / \mathrm{m} / \mathrm{h})\end{array}$ & $\begin{array}{c}\text { Age Max. } \\
\text { V. } 2 S \\
(h: m))\end{array}$ \\
\hline A001 & 3050 & 3,61 & 0,34 & 0,388 & $14: 07$ & 14 & $28: 30$ \\
\hline A101 & 3400 & 3,61 & 0,38 & 0,220 & $5: 37$ & 22 & $21: 30$ \\
\hline A201 & 3500 & 3,65 & 0,44 & 0,250 & $11: 52$ & 17 & $28: 30$ \\
\hline A301 & 3250 & 3,65 & 0,51 & 0,493 & $26: 00$ & 10 & $42: 30$ \\
\hline $\mathrm{A} 002$ & 4450 & 3,59 & 0,34 & 0,109 & $4: 45$ & 30 & $19: 30$ \\
\hline A102 & 3950 & 2,86 & 0,30 & 0,060 & $1: 45$ & 40 & $9: 38$ \\
\hline A202 & 5700 & 3,35 & 0,40 & - & - & 96 & $6: 56$ \\
\hline $\mathrm{A} 302$ & 5850 & 3,83 & 0,54 & 0,016 & $1: 30$ & 32 & 8:38 \\
\hline B001 & 3050 & 2,55 & 0,38 & 0,076 & $13: 35$ & 8 & $38: 30$ \\
\hline B101 & 3200 & 2,04 & 0,34 & 0,063 & $13: 35$ & 6 & $42: 30$ \\
\hline B201 & 2750 & 2,26 & 0,42 & 0,069 & $34: 00$ & 4 & $71: 30$ \\
\hline B301 & 2850 & 2,06 & 0,45 & 0,031 & $19: 35$ & 3 & $71: 30$ \\
\hline B002 & 5100 & 1,98 & 0,29 & - & - & 16 & 33:30 \\
\hline B102 & 5800 & 2,20 & 0,36 & - & - & 8 & $16: 30$ \\
\hline B202 & 6200 & 2,10 & 0,39 & - & - & 12 & $17: 30$ \\
\hline B302 & 5750 & 2,02 & 0,44 & - & - & 16 & $17: 30$ \\
\hline
\end{tabular}

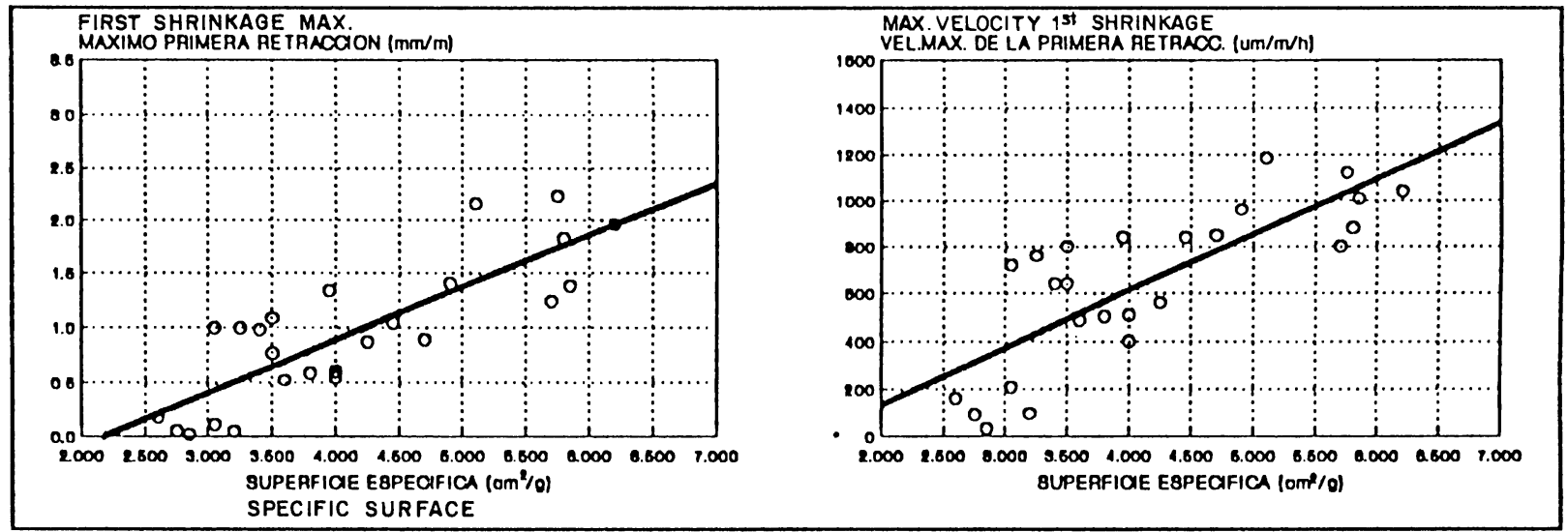

Fig. 12.-Efecto de la superficie específica en la primera

Fig. 12.-Speccific-surface effect on first shrinkage. retracción. 


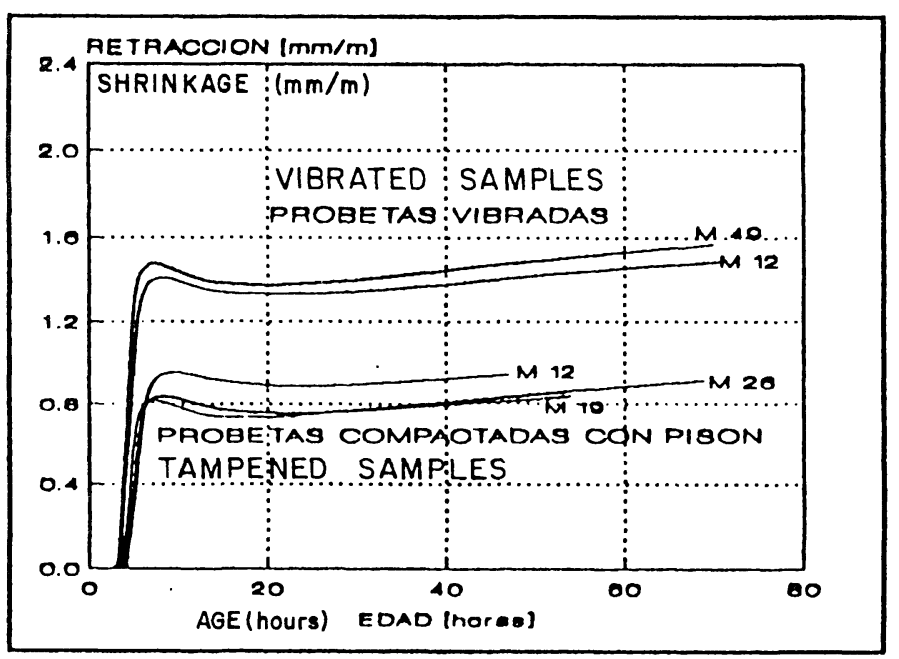

Fig. 13.-Efecto de la energía de compactación en el valor máximo de la primera retracción.

Fig. 13.-Effect of compactation-energy on the maximun value of first shrinkage.
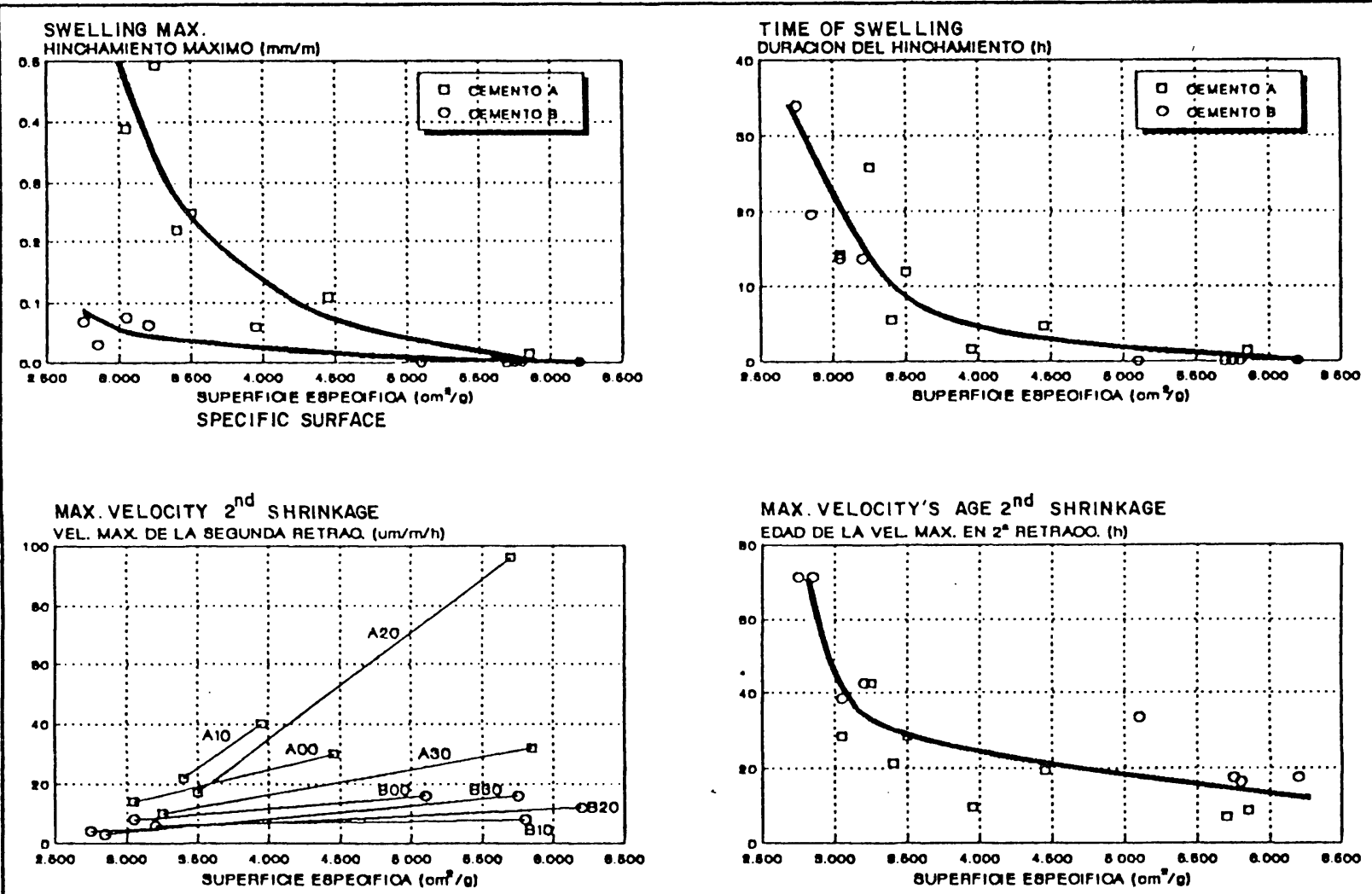

Fig. 14.-Efecto de la superficie específica en el hinchamiento y la segunda retracción.

Fig. 14.-Specific-surface effect on swelling and on second shrinkage.

En la Fig. 14 aparecen los efectos producidos por la superficie específica en los períodos de hinchamiento y de segunda retracción de pastas de cemento. Se observa que a mayor finura del cemento menor es el hinchamiento máximo y también es menor el período de tiempo que dura el proceso. Por otra parte, una mayor superficie específica implica que la velocidad máxima de segunda retracción es mayor y, a su vez, se presenta a más temprana edad.
Figure 14 shows the effects produced by the specific surface during the periods of swelling and of second shrinkage in cement pastes. It can be noticed that an increasing fineness of the cement is accompanied by a smaller maximum swelling and also by a shorter duration of the process. On the other hand, a larger specific surface implies a higher maximum velocity of the second shrinkage, and this maximum appears here at an earlier age. 
Fig. 15.- Influencia del contenido de yeso del cemento en el hinchamiento.

Fig. 15.-Influence of gypsum-contents of cement on swelling.
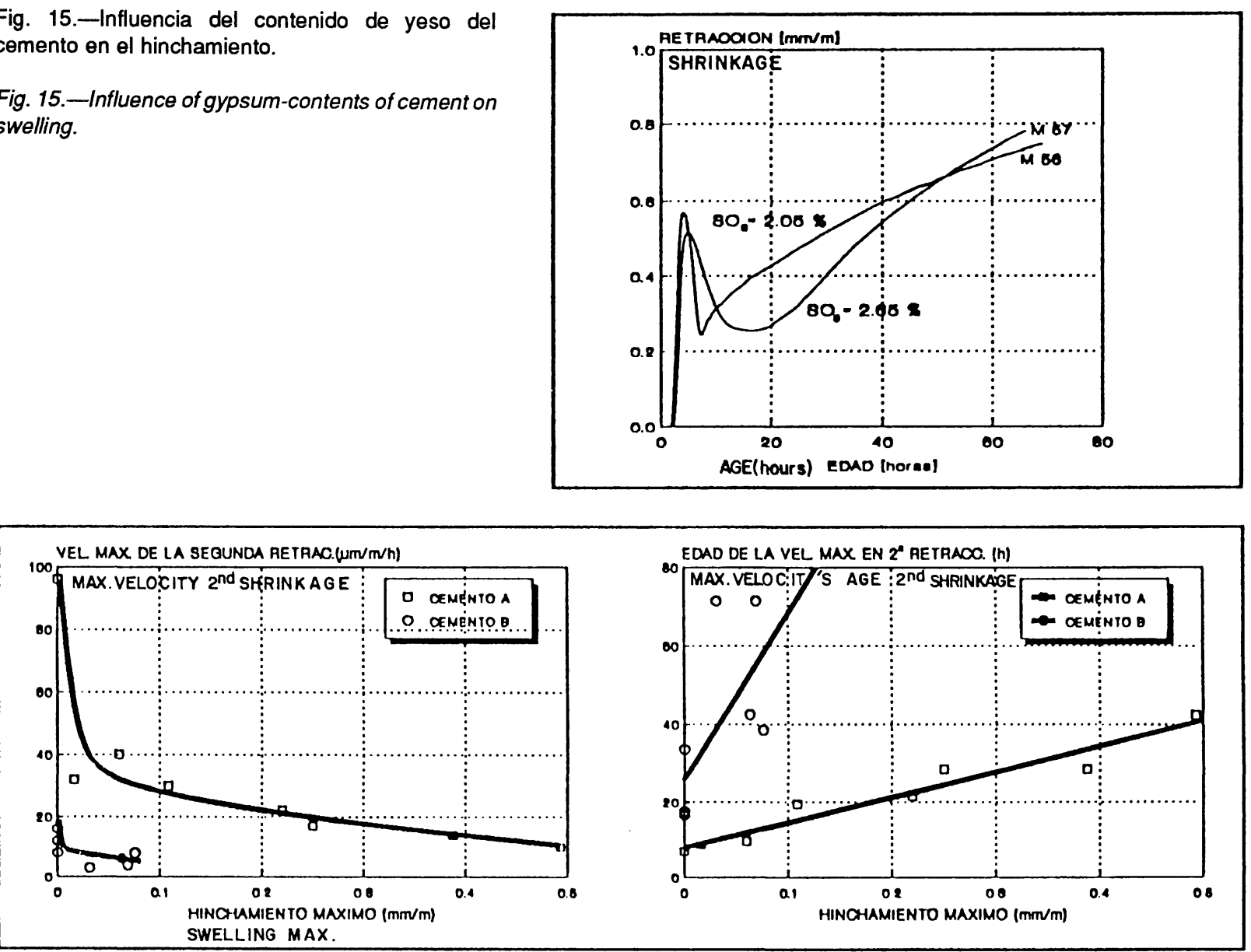

Fig. 16.-Correlación entre el hinchamiento y la segunda retracción.

Fig. 16.-Correlation between swelling and second shrinkage.

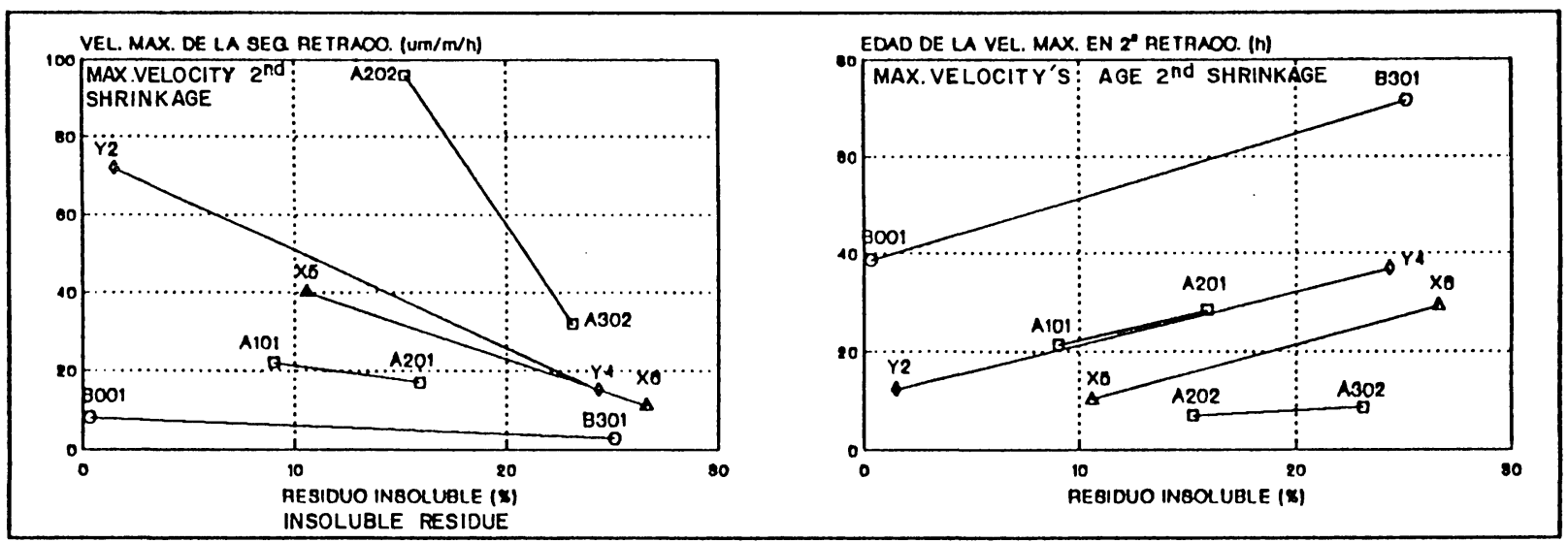

Fig. 17.-Efecto de la adición puzolánica en la retracción.

Fig. 17.-Puzzolan-addition effect on shrinkage.

Para observar el efecto del yeso sobre la retracción es útil la Fig. 15, la cual muestra que dos cementos de igual composición química y finura, pero de distinto contenido de $\mathrm{SO}_{3}$, forman curvas de hinchamiento diferente.

En la correlación de la Fig. 16 se observa que a mayor hinchamiento máximo disminuye la velocidad máxima de segunda retracción y logra que se produzca a una edad más tardía.
Figure 15 is usefull to observe the effect of gypsum on shrinkage; it shwos that two cements of like chemical coposition and like fineness but of different $\mathrm{SO}_{3}$ contents exhibit different swelling curves.

Figure 16 shows the correlation between swelling and second shrinkage, according to which an increasing maximum swelling is followed by a decreasing maximum velocity of second 
Para definir el efecto de adición puzolánica en el proceso de retracción hay que recurrir a la correlación de resultados obtenidos con cementos de similar composición química, igual finura y de la misma relación $\mathrm{SO}_{3}$ /clínker, pero de diferente contenido de residuo insoluble, factor que representa la adición puzolánica en los cementos. Dentro de los cementos ensayados, cumplen esas condiciones los que aparecen en la Fig. 17. Es posible apreciar que cuanto mayor es la adición puzolánica menor es la velocidad máxima de segunda retracción y se produce a una edad más avanzada.

\section{CONCLUSIONES}

1. Las experiencias sobre cementos chilenos, aquí detalladas, confirman la existencia de un proceso de retracción característico para cada cemento, que queda representado por un perfil de curva tipo, variable en valores máximos, tiempos de duración y velocidades, tanto en las secciones de primera y segunda retracción como, también, en la sección intermedia de hinchamiento. Las variaciones de primera retracción serían causadas por condiciones principalmente ambientales, pero también físicas y químicas del cemento; en cambio, las variaciones de las secciones de hinchamiento y de segunda retracción serían causadas solamente por condiciones físicas y químicas del material aglomerante.

2. Con relación al comportamiento de los cementos experimentales frente al fenómeno de la retracción, las mediciones registradas permiten apreciar que, aparte de las fases mineralógicas características de cada cemento, los factores de superficie específica, contenido de $\mathrm{SO}_{3}$, residuo insoluble (adición puzolánica) tienen una influencia muy importante en la retracción de las pastas en sus diferentes etapas de desarrollo.

\section{COMENTARIO FINAL}

Ambas retracciones darían origen a la fisuración del mortero o del hormigón en las obras, en el momento en que las tensiones provocadas por ellas superen las resistencias eventuales. Indudablemente, el inicio consiste en microfisuras de la fase pasta de cemento de carácter intergranular que seguirán evolucionando y propagándose en el material hasta alcanzar grados de fisuras o grietas o, simplemente, se detendrán en forma definitiva, dejando, tal vez, puntos o zonas más o menos débiles de la estructura. shrinkage, causing the appearance thereof at a more advanced age.

The definition of pozzolan-addition effect on shrinkage requires resorting to the correlation of results obtained using cements of similar chemical composition, of like fineness, and of like $\mathrm{SO}_{3}$ /clinker ratio, but of different isoluble-residue contents, factor representing the pozzolan addition to cements. Among the cements tested, those appearing in Figure 17 comply with these conditions. It is possible to observe that the larger the pozzolan addition the lower the maximum velocity of second shrinkage, and then this maximum is produced at a more advanced age.

\section{CONCLUSIONS}

1. The herein discussed experiences using chilean cements confirm the existence of a shrinkage process that is characteristic for each cement and that is represented by a typical curve-shape variable as to maximum values, duration times and velocities, both in the sections of first and second shrinkages as well as in the intermediate section of swelling. First-shrinkage variations would be caused by conditions principally ambiental, but also physical and chemical, of the cement; on the other hand, the variations in the sections of swelling and second shrinkage would be caused only by physical and chemical conditions of the agglomerant material.

2. As regards the behaviour of the experimental cements in connection with shrinkage phenomenon, the recorded measurements allow to deduce that, aside from the characteristic mineralogical phases of each cement, the factors of specific surface, $\mathrm{SO}_{3}$ contents, insoluble residue (pozzolan addition), are exhibiting a very important influence on the shrinkage of the pastes during their different stages of development.

\section{FINAL COMMENT}

Both shrinkages would cause the fissuration of the mortar or concrete in the constructions as soon as the stresses originated by the same would exceed the eventual resistances. The initiation is undoubtedly due to microfissures of intergranular nature in the cement-paste phase, and such microfissures will continue to evolve and propagate through the material till reaching the state of fissures or craks, or else they will simply stop finally, leaving some more or less weak points or zones in the structure. 
Por tales razones, el conocimiento profundo de la retracción del mortero o del hormigón a nivel pasta de cemento es fundamental para dominar los efectos dañinos del fenómeno (16). Debe estudiarse especialmente la segunda retracción, que puede considerarse una propiedad de reciente conocimiento específico, que necesita complementarse con informaciones de la acción sobre ella de todos los productos que participan en la hidratación: cementos, adiciones, aditivos, etc.

El método de ensayo, desarrollado en este trabajo, permitirá a fabricantes y constructores seguir el conocimiento de esta característica, juzgar su importancia práctica y controlarla, si se desea evitar sus efectos en elementos estructurales de hormigón.
Owing to such reasons the deep knowledge of mortar or concrete shrinkage during the cement-paste stage thereof is fundamental for overcoming the demaging effects of the phenomenon (16). A special study should be devoted to the second shrinkage, which is a property representing a recent and specific knowledge that requires to be complemented with information regarding the action, on this shrinkage, of all the products partaking in hydration, namely: cements, additions, additives, etc.

The testing method developed thruogh this work will enabla manufactures and constructors to continue enlarging the knowledge of this characteristic, to judge its practical importance and to control it whenever wishing to avoid its effects in structural elements of concrete.

\section{REFERENCIAS BIBLIOGRÁFICAS}

\section{BIBLIOGRAPHIC REFERENCES}

(1) BARON, J.: Les retraits de la pate de ciment in "Le Béton Hidraulique". París, Presses de l'Ecole Nationale des Ponts et Chausseées. 1982.

(2) DE HASS, G.D.; KREIJGER, P.C.; NIEL, E.M.M.G.; SLAGTER, J.C.; SETEIN, H.N.: "The shrinkage of hardening cement paste and mortar", Cement and Concrete Research, Vol. 5, pp. 295-320. 1975.

(3) RAVINA, D.; SHALON, R.: "Plastic shrinkage cracking" Jour. A.C.I., Octubre, 1968.

(4) JAEGERMANN, C.J.; GLUCKLICH, J.: "Effect of high evaporation during and shortly after casting on the creep behavior of hardened concreten RILEM, Matériaux de construction, Vol. 2, N. $97,1969$.

(5) WITTMANN, F.H.: "On the action of capillary pressure in fresh concrete". Cement and Concrete Research, Vol. 6, pp. 49-56. 1976.

(6) BARON, J.: "Fissuration du béton par hydratation localement différée du ciment". Laboratoires de Ponts et Chaussées, Raport de Recherche N. 15, Mayo 1971.

(7) DEL CAMPO, M.: "A new method to study the early volumen changes on the neat cement paste", Bol. RILEM 4, pp. 18-23, 1959.

(8) L'HERMITE, R.; CHEFDEVILLE, J.; GRIEU, J.J.: "Nouvelle contribution a l'etude du retrait des ciments" Annales ITBTP, N. 2 106, pp. 1-27, Diciembre 1949.

(9) BARON, J.: "Essai sur une vue d'ensemble de la fissuration spontanée accidentelle du béton hydraulique non armé et armé". Bol. Liaison Labo. P. et Ch., 87, pp. 69-78, Enero-Febrero 1977.

(10) OSSA, M.; MARCANTONINI, C. y COFRE, f.: "Retracción de pastas de cemento en estado plástico y en la primera etapa de endurecimiento". Materiales de Construcción. Vol. 34, N.e 194. Madrid, España. Mayo/Junio 1984.

(11) RAVINA, D.; SHALON, R.: "Shrinkage of Fresh Mortars Cast Under and Exposed to Hot Dry Climate Condicions". RILEMCEMBUREAU. Colloquium on the shrinkage of hydraulic concretes. Madrid 1968. Proceedings Bb II, Beitrag III-E.

(12) DUTRON, R. et MOMMENS, A.: "Retrait plastique des mortiers et beton frais", Bulletins Technique N. ${ }^{2} 65$. Laboratoire d'essais et de contrôle du Groupement des producteurs de ciment de Belgique (G.P.C.).

(13) OSSA, M. y ROSALES, O.: "Comportamiento de morteros de cemento en estado fresco". Trabajo de investigación aún no publicado.

(14) BARON, J.; EL KASSEM, N.; GUIEYSSE, B., "Desarrollo de un ensayo simplificado de la segunda retracción". Bull Liaison Labo, P. et Ch., 1989.

(15) OSSA, M. y GONZALEZ, J.: "Retracción del hormigón. Efectos de tipos de cemento, formas de grava y métodos de compactación". V Jornadas Chilenas del Hormigón, Concepción, 25 al 27 de Octubre, 1984. 